Article

\title{
Sustainable Management of Sports Federations: The Indirect Effects of Perceived Service on Member's Loyalty
}

\author{
Pedro Cuesta-Valiño ${ }^{1, *(1)}$, Pablo Gutiérrez-Rodríguez ${ }^{2, *}$ and Cristina Loranca-Valle ${ }^{1, *}$ \\ 1 Department of Economics and Business Management, University of Alcalá, 28802 Alcalá de Henares, Spain \\ 2 Department of Business Administration, University of León, 24071 León, Spain \\ * Correspondence: pedro.cuesta@uah.es (P.C.-V.); pablo.gutierrez@unileon.es (P.G.-R.); \\ cristina.loranca@uah.es (C.L.-V.)
}

Citation: Cuesta-Valiño, P.; Gutiérrez-Rodríguez, P.;

Loranca-Valle, C. Sustainable Management of Sports Federations: The Indirect Effects of Perceived Service on Member's Loyalty. Sustainability 2021, 13, 458. https://doi.org/10.3390/su13020458

Received: 20 December 2020 Accepted: 31 December 2020 Published: 6 January 2021

Publisher's Note: MDPI stays neutral with regard to jurisdictional clai$\mathrm{ms}$ in published maps and institutional affiliations.

Copyright: $(\odot 2021$ by the authors. Licensee MDPI, Basel, Switzerland. This article is an open access article distributed under the terms and conditions of the Creative Commons Attribution (CC BY) license (https:// creativecommons.org/licenses/by/ $4.0 /)$.

\begin{abstract}
Sports federations are non-profit organizations that compete for members and resources. These organizations are obliged to cooperate on the environment, nature conservation, and sustainability together with other public bodies. Given this situation and the necessity to differentiate themselves from commercial sports providers, it is essential for sports federations to create loyalty. The objective of this article is to provide an in-depth study of the variables that explain federation members' loyalty, which is the best tool for federations to meet their sustainable and non-profit objectives. Having made an exhaustive review of the literature on loyalty, an empirical study is made of the loyalty antecedents (service quality, satisfaction, trust, and commitment), using a questionnaire of members of all of Spain's karate federations. This empirical study has led to a model of structural equations that gives a perfect explanation of loyalty based on the relationships between the various variables, starting with service quality and considering the other variables to be mediating variables between service quality and loyalty. Furthermore, the findings show that service quality is the best option for improving member loyalty through some of the mediators proposed.
\end{abstract}

Keywords: sport marketing; sport organization; loyalty; sustainable management; service quality; satisfaction; trust; commitment

\section{Introduction}

As sports services come under increasing scrutiny from stakeholders to ensure activities are beyond reproach, sport needs to be increasingly sustainable from local to global levels. It is, therefore, particularly important that organizations within the non-profit sport sector-such as federations-demonstrate sustainability, safety, and integrity [1]. Sponsors at every level want to be sure they are not aligning themselves with organizations that present a reputational risk, and federations as non-profit sporting organizations need financial support from public and private institutions to organize sporting activities [2,3]. Today, if federations want to receive that support their activity must be sustainable. Unlike for-profit organizations, federations are not focused on making profits; rather, their purpose is social and societal [4-6]. Due to extensive political corruption, scandals, a lack of transparency and sustainability problems in international and local federations, entities that ought to be engaging in a sustainable management now find themselves under scrutiny [7,8]. Fullerton and Merz [9] note that despite the economic success of non-profit sports organizations and their social purpose being acknowledged, there is insufficient sports marketing literature that discusses these organizations.

The main purpose of a Spanish sports federation-a mixed (public-private) nonprofit organization-is to promote and advance the sport in question [10]. Although such institutions are private entities, it is government authorities that legitimize and validate them as bodies for the development of high-level and high-performance sport, and it is governments that provide federations with their principal financial resources. 
The current paper contributes to the knowledge of customer loyalty in the sector of sports federations, and in developing this theoretical framework it offers a way for federations to achieve support and secure a sustainable future. According to Wemmer and Koenigstorfer [11], the growth in non-profit sport organizations is not proportional to the increased interest in physical activity and sport in the population as a whole. Sports businesses have grown considerably in recent years, and increasing numbers of consumers engage the services of this type of company. Nevertheless, non-profit organizations are not benefiting from this period of growth in the sector as much as sports businesses are; in other words, they are not tackling the growing competition [12].

There are two possible causes for the situation the federations find themselves in. One is a loss of members due to their disappointment with the service quality provided by the organization; the other is a failure to acquire sufficient new members. This paper focuses on the first possible cause. A loss of members may result in a lack of growth in the number of licensed members, with loyalty acting as key variable in this respect since it is one of the most important attitudinal variables [13]. If federations offer to their members sustainable and non-profit objectives, they can improve loyalty. This approach can help to implement customer loyalty strategies in the non-profit sector to drive success in member loyalty achievement. Our analysis of federation members' loyalty may be very useful to federation directors, since it will give them greater knowledge of their membership and improve their chances of maintaining licensed member numbers by implementing marketing strategies $[14,15]$.

The subject of this empirical study is membership of Spanish karate federations. The organizational structure of the Spanish Karate Federation is formed by 19 regional karate federations, which have 1441 member clubs and 75,406 member athletes, which represents an average of 52.33 member athletes for each karate club. This data is very similar to the total number of sports federations in Spain, since there are 3,945,510 member athletes in 75,455 sports clubs in Spain, which represents an average of 52.29 member individuals for each sports club [16-19]. In the case of karate federations, the karate clubs are the intermediaries between the federated athletes and the federations, since the clubs are the ones that carry out all the relationships between their athletes and their federations. Moreover, the federations are the ones that organize all the official regional and national competitions, as well as the official training, official qualifications courses, and black belt exams. In addition, these are the main services that the karate federations offer to their members [20,21]. Interest in karate started to grow in Spain in the 1960s and it is currently one of the top 12 sports in the country in terms of federation member numbers. In 2016, the International Olympic Committee unanimously approved the inclusion of karate in the Tokyo 2020 Olympics [22]. Sustainability is at the heart of the Olympic Movement's philosophy and the International Olympic Committee integrates sustainability across their operations and events. Karate has been selected for this study because Spain's karate federations - and those of other countries worldwide-will experience exceptional increases in member numbers due to the promotional effect of karate becoming an Olympic sport. Therefore, federation directors need to know how to manage the loyalty of all these new members in such a way as to keep them satisfied, in line with the purposes of a non-profit sustainable organization.

\section{Conceptual Framework and Hypothesis}

\subsection{Research Framework}

One of the main objectives of this study is to understand loyalty in the sports federation context: To this effect, in Figure 1 sets out the model that has guided this research. This model summarizes the connections and relations between the different constructors described in the hypotheses. According to this proposed model, service quality may impact loyalty through satisfaction, trust and the different dimensions of commitment (affective, conative, and cognitive). 


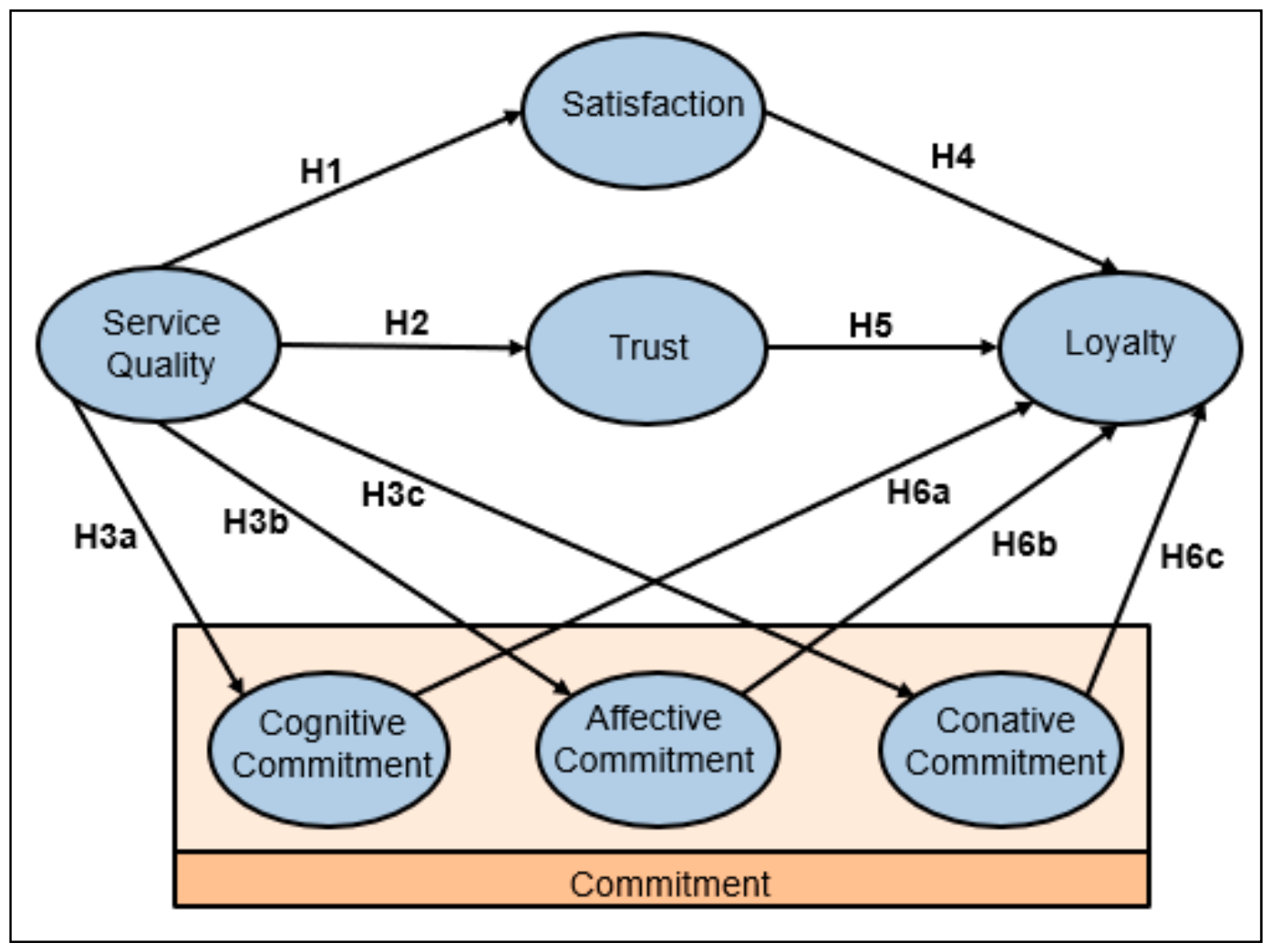

Figure 1. Model of Federated Sportspeople Loyalty.

\subsection{Research Hypothesis}

According to Zeithaml [23], perceived service quality refers to the consumer's judgment or attitude relative to the general excellence or superiority of a service. Perceived service quality differs from objective quality [24]. To measure service quality, Parasuraman et al. [25] proposed a comprehensive model comprising ten dimensions of service quality which was simplified under the name SERVQUAL [24]. This new five-dimension scale has been widely recognized and adopted in various fields [26-30]. SERVQUAL dimensions use aspects such as (1) tangibles, (2) reliability, (3) responsiveness, (4) assurance, and (5) empathy. However, the scale is based on the comparison of perceived quality of service received and customers' expected service quality [31], an approach that has been criticized by various authors [32-34]. In response to the criticisms raised, a scale was designed that focused on customers' perceptions of service provider performance. Cronin and Taylor [35] developed the scale under the name SERVPERF. However, this scale has also received criticism because it is considered too generic for use in specific industries. Although different models have been proposed for analyzing service quality in specific industries [36-40], federations are not taken into account in the previously proposed models. The closest studies to be found focus on public and private sport organizations that deliver sport and fitness sport [41]. In any case, thus far there is no consensus on the items or dimensions making up its composition [42]. Since the 1980 s, a variety of tools have been employed to study perceived quality [43,44]. Subsequent studies are rooted in Brady and Cronin [45], who researched physical quality, environment quality, and outcome quality dimensions. Recent papers adapted the aforementioned dimensions to encompass staff interaction, facilities and expected results $[46,47]$ in public and private sport organizations [48-50]. In practice, modifications are needed to reflect the specific characteristics of the federation service context being studied in line with the ideas contained in these more recent models. Overall service quality has mainly been used as a reflective construct $[41,42,51-54]$ but it is not use second order construct because, in a more 
complex models, the final aim is determining not the importance of model dimensions but the role of perceived service quality in its relations with other variables $[37,38,40]$.

Meanwhile, satisfaction is the perceived discrepancy between prior expectation and perceived performance after consumption [55]. Other authors define satisfaction as the customer's emotional or sentimental reaction to the perceived differences between expectations and actual implementation [56,57]. Following this emotional concept, satisfaction has been considered a "subjective evaluation made as a post-choice cognitive judgment" [58]. Satisfaction defined as judgment has been included in recent research $[59,60]$, and although this definition could cause confusion due to its similarity with the definition of perceived service quality, the two variables are definitely distinct from each other, the principal difference being that satisfaction is a type of attitude-a perception over the long termwhile perceived service quality measures a specific transaction [24]. Deng, Lu, Wei, and Zhang [56] relate satisfaction to providing what is being sought to the point where fulfilment is reached. In the current research, this concept has been understood to be customers' cumulative experiences [61], mainly because the relationship between a sportsperson and their federations is, in most cases, ongoing for the duration of the member's license.

Service quality has been considered a predictor and strong antecedent of customer satisfaction [62-66], but various authors consider satisfaction to be an antecedent of perceived service quality. In search of findings to explain this disparity, Han et al. [67] investigated the relation between perceived service quality and satisfaction where satisfaction is an antecedent of customer satisfaction in different fields. They revealed a strong connection between perceived service quality and customer satisfaction where service quality was an antecedent of satisfaction. There is evidence within the sports service sector of a causal relationship between service quality and satisfaction. This relationship in private facilities has been demonstrated in various studies [53,68-71] but there is a lack of studies on the public sector or public interest sport organizations such as federations, and only a few recent studies confirm this relationship [41,54].

Based on the above considerations, the following research hypothesis is proposed:

Hypothesis 1 (H1). Service quality has a positive influence on the satisfaction of sports federation members.

Trust has been studied in a wide range of fields with a focus on the personal characteristics of trust and the institutional aspects of trust or reliability [72]. In business, trust is considered one of the principal ingredients of successful relationships [73,74]. Anderson and Weitz [75] define trust as the consumer's belief that the actions the other party takes will necessarily satisfy his/her needs. Trust is also an expression of enduring beliefs stemming from the other party's action [76], encapsulating the belief that the company will be true to their word [77]. In sports, it is especially important to understand that trust plays the role of a strategic resource, helping to achieve a competitive advantage [78]. Trust is an attribute that makes members of a sport organization interact with full engagement with the company to implement the variety of strategic objectives which enable an organization to meet its targets [79]. Long-term relationships are emphasized because trust is the intermediary for maintaining this kind of relationship with the organization [80,81]. Although research on trust in sports has been scarce, this idea has been repeated several times in the literature $[74,81,82]$, and it is possible to find surveys on brands [83,84] or consumers [81].

Many authors agree that trust in an organization is based on the consumer's certainty of the quality and integrity of the service offered $[81,84,85]$. Trust appears to be an important reason consumers may be willing to pay more for products [86], and several surveys confirm the positive role of perceived service quality on trust $[86,87]$. Based on this evidence, it is expected that consumers who evaluate the service quality of federation as higher are more likely to trust in this organization. In the sports sector, there are theories that point to a tenable relationship between the concept of sports consumer trust and sports organizations' service quality [88]; trust can even be considered an essential component of service quality [89]. 
According to these considerations, the following hypothesis is postulated:

Hypothesis 2 (H2). Service quality has a positive influence on the trust of sports federation members.

Commitment is proposed as a central concept in the literature on social exchange and buyer behavior [81] and is also a key variable in marketing perception research [84]. First, in marketing, the most common definition of "commitment" states that maximum effort is required to maintain the relationship between the parties [74,90,91]. Thus, commitment implies the conviction of both parties that maintaining the relationship will be more beneficial than ending it [90]. In the context of sport, commitment has been defined emphasizing the ongoing effort required of sports consumers to continue a relationship with a particular sport organization [92-94]. Together with trust, commitment has been the most commonly accepted variable in perceived service quality models $[74,81,82,84]$. Once again, sport commitment has been used as a key construct to explain the relationship between sports consumers and sports organizations, and it has a significant role in the sports consumption decision [89,92,95-98].

All definitions of commitment agree that it has psychological and motivational components [99]. Starting from this premise, most recent studies analyzing this situation identify commitment as a multi-dimensional construct. Consequently, commitment can be understood to have three dimensions [99-102] and its state involves affective, cognitive, and conative components [103]. Clients may experience each of these three components-which are also psychological states-to differing degrees. The net sum of a person's commitment to an organization therefore reflects each of these separate psychological states. Given the conceptual differences between the dimensions of commitment, it seems reasonable that each of these three components develops independently from the others [100].

Cognitive commitment refers to the feeling of obligation towards the organization, and is related to the idea "should maintain the relationship" [100,101,104]. Cognitive commitment is defined as the obligation to remain loyal to an organization for ethical or moral reasons $[105,106]$. This component of commitment is influenced by individual experiences of socialization before and after the exchange relationship occurs [107]. The commitment may be stronger if, prior to the exchange relationship, the consumer's friends or family members have been linked to the organization, or if the strategies proposed by the organization are orientated towards winning the consumer's loyalty [100,108-111]. Cognitive commitment as a commitment component has an antecedent in perceived service quality in business models [81] and the sports sector [89]. Some authors have included cognitive commitment as an independent component that develops a relationship with perceived service quality commitment [112] even in relations between sports consumers and sports organizations [113].

In early studies of commitment, authors mainly focused on studies of cognitive commitment, but in recent decades there have been in-depth studies of how the consumer's emotions influence relationships between the service provider and the client [114]. If commitment has been defined as a psychological attachment to the organization [101] then affective commitment improves commitment relationships [115-118]. The affective dimension reflects the individual's desire to maintain the relationship, their emotional bond with the organization that motivates them to continue the relationship [100,101,104,106]. Affective commitment reveals the consumer's feeling of belonging to and participating in the activity of the service provider, expressing the emotional bond between the two $[114,119]$. Several authors have demonstrated a relationship between service quality and customer affective commitment [120-122] providing strong empirical evidence for a direct and positive influence of perceived service quality on affective commitment [123]. This strong and direct positive influence can be also be found in sport organizations [122,124].

The conative dimension reflects the perceived consumer sacrifice involved in ending the relationship with the service offered by the organization $[100,101,104]$. This type of commitment could also be conceptualized as the perceived financial value of continuing the relationship with the organization compared with the value of abandoning the rela- 
tionship [106]. Conative commitment has been developed based on two factors: The size and/or number of investments the consumer has made, and a perceived lack of alternatives [100]. Different surveys in a range of sectors have attempted to prove the relationship between conative commitment and service quality [112]. Xie [122] examined the factors that influence internal service quality level in a public sport organization and a model was developed where affective organizational commitment, cognitive organizational commitment, and conative organizational commitment were service quality antecedents.

Based on the above theories, the following set of hypotheses is proposed:

Hypothesis 3a (H3a). Service quality has a positive influence on the cognitive commitment of sports federation members.

Hypothesis $\mathbf{3 b} \mathbf{b} \mathbf{H} 3 \mathbf{b})$. Service quality has a positive influence on the affective commitment of sports federation members.

Hypothesis 3c (H3c). Service quality has a positive influence on the conative commitment of sports federation members.

Loyalty is fundamental to the success of any business [125]. Those firms that achieve a high number of loyal customers may raise their competitive advantage and, in turn, their profits, which is the final aim of any firm [126]. Before focusing on the antecedents of loyalty, it is necessary to define this variable.

The concept of loyalty is identified with the continuance of the service, [127]. In other words, consumers that return several times to get the service they desire from the same company are loyal customers [39]. Several authors have supported the definition of loyalty posed by Oliver [128], in which loyalty is defined as a strong commitment to re-purchase favorite goods or services consistently in the future, despite the marketing efforts of the competition and other situational influences that could result in switching behavior.

Generating loyalty not only results in repeat practice by the consumer: it is also decisive in helping them acquire healthy lifestyle habits. In the context of sports, loyalty includes attitudinal and behavioral aspects [129]. Loyalty comprises a set of consumer intentions that will subsequently become behaviors [130] and there are some situational, intrinsic, social and cultural factors that indicate that loyalty is more than just a repeat purchase behavior [131]. This variety of factors may include high switching costs; stock-outs; choice restricted by location, money or time; and customer habits [132]. In summary, these postulates indicate that loyalty should be analyzed from two dimensions (behavioral and attitudinal). The behavioral perspective examines some factors involved in the purchase: the sequence, the reason and the scope, or a combination of all three [133]. The attitudinal component is linked to users' preferences and affections [134,135].

Theory defends that satisfaction has a positive impact on loyalty [136]. This strong relation has contributed to maximizing customer satisfaction [104], loyalty being the final goal of measuring customer satisfaction. This is the key that determines a company's long-term viability [137]. In contrast, dissatisfaction leads to switching behaviors and to companies being criticized in a way that affects that affect current and potential consumer behaviors [138].

Satisfaction is one of the most widely recognized antecedents of loyalty, since many authors have demonstrated empirically the relationship between both variables in different fields $[62,85,128,139,140]$. This relationship has special relevance in the service sector, because both constructors have been studied in depth [39,104,141,142]. In sport contexts, a range of studies have researched the relationship between satisfaction and loyalty [127,143-147]. A large proportion of these papers confirmed the influence of satisfaction on sport center loyalty (in the context of clubs, health centers and skiing resorts) [146-148]. Calabuig, Prado-Gascó, Crespo, Núñez-Pomar, and Añó [144] focused their research on club membership loyalty, while Alexandris and Kouthoris [149] and Castillo-Rodríguez and Onetti-Onetti [145] have concentrated on educational sport activi- 
ties. In this area, there are some cases that are especially notable because they also include service quality in their models of satisfaction and loyalty [144-147]. In these papers, the relationship between service quality, satisfaction, and loyalty is confirmed.

Based on the reviewed literature, the following hypothesis is postulated:

Hypothesis 4 (H4). Satisfaction has a positive influence on the loyalty of sports federation members.

Several authors have sustained that trust is one of the most decisive factors in loyalty in the buyer-seller relationship $[81,85,101,150-153]$. When a consumer trusts a corporation, they tend to increase their levels of loyalty and to recommend the service provider to other potential consumers $[62,154,155]$. Furthermore, trust derived from a service interaction reduces the risk perceived by customer, making it possible to increase the price of the service since the consumer considers trust to be an extra benefit and they are willing to pay more for it [81,155].

This positive relationship between trust and loyalty is widely supported in the electronic and digital sectors since internet purchases largely depend on the degree of trust [156-159]. However, the service sector is the main framework within which the theory confirms the link between both variables $[93,97,151,153,155,160]$.

Specifically, in the sports sector, there are various studies that support the positive impact of trust on consumer loyalty $[89,161-165]$. Just as in other industries, trust is a relevant constructor in digital sports products [22,162]. Meanwhile, fan trust is a key determinant generating team loyalty, as some researchers have demonstrated $[162,165]$. Another aspect of sports in which the relationship between trust and loyalty has been validated is loyalty to sports clubs [164,165]. In particular, Schijns, Caniëls, and Le Conté [164] affirm that trust mediates between service quality and loyalty.

Taking in consideration these concerns, the following hypothesis is proposed:

Hypothesis 5 (H5). Trust has a positive influence on the loyalty of sports federation members.

Several surveys reveal that commitment in organizations has a positive relationship with loyalty, discussing the importance of the three dimensions of commitment to loyalty $[106,166,167]$. Nevertheless, while commitment and loyalty are closely related, they are in fact different constructs. Loyalty reflects the attitudes and behaviors that commitment evokes [67], while commitment shows the strength or stickiness of the relationship [168]. Empirical research in the services context supports the notion that commitment has a direct and positive influence on loyalty [169-171]. In the sports sector, loyalty accompanies commitment in empirical behavior models [172] and these are the key factors influencing the sports consumer relationship. From the point of view of sport organizations, different studies therefore choose commitment towards loyalty as the variables of interest because of their great importance to marketers [173].

This study analyses the relationship between the three dimensions of commitment and loyalty. Regarding cognitive commitment, few studies examine the relationship between this dimension and loyalty or attitude and behavioral components [174]. In consumer behavior contexts, Bloemer and Odekerken-Schröder [175] finds a positive effect of cognitive commitment on attitude loyalty. The findings of Bloemer and Odekerken-Schröder [175], Bansal, Irving and Taylor [176] and De Ruyter, Moorman and Lemmink [177] propose that cognitive commitment has a positive effect on behavioral loyalty. In the sports sector, it is also very difficult to find studies that analyze this relationship. In any case, it is proposed that in sport organizations there is a strong a positive relationship between cognitive commitment and loyalty [178].

Affective commitment positively influences customer loyalty $[85,174]$ and generates intention to preserve and strengthen this relationship [91,177,179-181]. Meyer, Stanley, Herscovitch, and Topolnytsky [182] conclude that the effects of affective commitment are stronger than those of cognitive commitment on organizational commitment, but this situation is not confirmed in consumer commitment and the positive effect of affective 
commitment on consumer loyalty [180,183-185]. In the sphere of sport, there are strong emotional responses in which sports consumers build a relationship with the organization [186]. For this reason, affective commitment has a positive influence on levels of loyalty $[187,188]$.

Previous research has indicated that cognitive and affective commitment are a relevant indicator of loyalty [189]. In addition, loyalty is affected positively by conative commitment because customers with a lack of alternatives tend to return. To retain customers, it is important that organizations develop a service that will make consumers think there is more to be lost than to be gained if you leave the organization [190]. Finally, several surveys show conative commitment is a relevant antecedent of loyalty inside the sport commitment concept [104,191]. Again Kim [192] develops the important relationship between commitment and the conative aspect of loyalty in sport.

Considering these factors, the following set of hypotheses is suggested:

Hypothesis 6a (H6a). Cognitive commitment has a positive influence on the loyalty of sports federation members.

Hypothesis $\mathbf{6 b} \mathbf{( H 6 b ) . ~ A f f e c t i v e ~ c o m m i t m e n t ~ h a s ~ a ~ p o s i t i v e ~ i n f l u e n c e ~ o n ~ t h e ~ l o y a l t y ~ o f ~ s p o r t s ~}$ federation members.

Hypothesis $6 \mathrm{c}(\mathbf{H 6 c})$. Conative commitment has a positive influence on the loyalty of sports federation members.

\section{Methods}

\subsection{Survey Design}

This research is based on a cross-sectional descriptive study using primary data from a questionnaire answered by a representative sample of athletes affiliated to karate federations in Spain from March 2019 to December 2019. The total number of athletes that were members of Spanish karate federations in 2019 was 75,406 [19]. The total number of valid questionnaires collected was 629 , implying a sampling error of $\pm 0.97 \%$ (with a $95.5 \%$ confidence interval and $\mathrm{p}=\mathrm{q}=0.5$ ). (See Table 1 ).

Table 1. Technical data sheet.

\begin{tabular}{cc}
\hline Universe & Athletes of Karate Federations in Spain (75,406 Athletes) \\
\hline Geographical scope & Spain \\
Field work & From March 2019 to December 2019 \\
Sampling & Discretionary non-probabilistic by quotas \\
Sample & 629 valid surveys \\
Sample error & \pm 3.97 with a 95.5\% confidence level and $\mathrm{p}=\mathrm{q}=0.5$ \\
\hline
\end{tabular}

The questionnaire is composed of two main sections. In the first part, data are collected about the demographic characteristics and behavior of respondents. The second part examines the dimensions analyzed. For this part, the initial selection of the different items of the seven constructs of the questionnaire was based on an exhaustive review of the literature. Once the items had been selected, and before sending out the questionnaire, prior qualitative research was carried out through a focus group. This focus group was comprised of three professors from different Spanish universities with expertise in sport marketing, three professionals who work in different karate federations, and three athletes that are members of karate federations. As a result of this qualitative research, the final questionnaire was obtained, consisting of seven constructors with a total of 34 items (see Table 2). 
Table 2. Items by construct.

\begin{tabular}{cc}
\hline Construct & Number of Items \\
\hline Service Quality & 5 \\
Loyalty & 3 \\
Satisfaction & 3 \\
Trust & 4 \\
Affective commitment & 2 \\
Conative commitment & 2 \\
Cognitive commitment & 2 \\
\hline
\end{tabular}

The questionnaire included multiple-item measurement scales adapted from the review of the literature that help to ensure the validity of measurement scales for all constructs: five items for service quality $[24,62,65,66]$, three for loyalty $[62,140]$, three for satisfaction [62], four for trust $[62,89,156,158]$, two for affective commitment $[85,110,118]$ two for conative commitment [104] and two for cognitive commitment [108,109,111] (See Table 3).

The scale used for these 34 items was a five-point Likert-type response format, in which respondents could rate the items from 1 ("completely disagree") to 5 ("completely agree"). It also included questions on a series of general classification variables (gender and age) and others specific to members of karate federations (years of membership of their karate federation and their main activities within that federation).

A pre-test of the questionnaire was carried out in February 2019 on a representative sample of athletes from karate federations in Spain, made up of 30 people between 15 and 70 years of age, 21 men and 9 women, which is the proportion of men and women who are members of karate federations in Spain [19]. The aim of this pre-test was to determine whether the scales were well constructed and to ensure that the people to whom the survey was to be addressed understood each of the questions in the questionnaire perfectly. After this process, some typos were corrected, and all questions were validated. Once the questionnaire had been refined, it was launched online through a discretionary non-probabilistic sampling by quotas, with the aim of achieving a distribution of sexes as similar to possible to that of the population who are members of karate federations in Spain. The questionnaire was distributed through the main social networks in March 2019 and through karate federation websites from March 2019 to December 2019. The result was that a representative sample of the population was studied, with a total of 629 valid questionnaires.

\subsection{Sample Size and Composition}

The total sample size was 629 individuals who represent athletes of karate federations in Spain. The composition of the sample was $71 \%$ male and $29 \%$ female. By age group, $20 \%$ are less than 16 years old, $27 \%$ are $16-29$ years old, $19 \%$ are $30-44$ years old, $32 \%$ are 45-64 years old and 3\% are more than 64 years old. By years of membership, the most numerous groups are the athletes with more than 20 years of membership (33\%), the athletes with 11-20 years of membership (24\%) and the athletes with 6-10 years of membership (23\%). In addition, finally, from the point of view of the activities most indemand among the members of the karate federations, these are courses $(58 \%)$, training sessions (53\%), competitions ( $49 \%$ ) and exams ( $42 \%)$. Table 4 provides descriptive statistics for the sample. 
Table 3. Scales of the model's constructors.

\begin{tabular}{|c|c|c|}
\hline Construct & Item & $\begin{array}{l}\text { Supporting } \\
\text { Literature }\end{array}$ \\
\hline Service quality & $\begin{array}{l}\text { The management of the activity was handled efficiently } \\
\text { Employees responded promptly to my requests } \\
\text { The hotel provided a pleasant atmosphere } \\
\text { Charges on my account were clearly explained } \\
\text { The offerings of the service provider are of high quality }\end{array}$ & {$[24,65]$} \\
\hline Loyalty & $\begin{array}{l}\text { I will continue to use the federation services if any } \\
\text { I will recommend others to use the federation service } \\
\text { Even if close friends recommended another service, my preference for the federation } \\
\text { service would not change }\end{array}$ & {$[62,140]$} \\
\hline Satisfaction & $\begin{array}{l}\text { My choice to the federation service is a wise one } \\
\text { I think I did the right thing when I subscribed to this federation service } \\
\text { Overall, my feeling to the federation service is satisfactory }\end{array}$ & [62] \\
\hline Trust & $\begin{array}{l}\text { Based on my experience, I know the federation service provider is honest } \\
\text { Based on my experience, I know the federation service provider cares about customers } \\
\text { Based on my experience, I know the federation service provider is trustworthy } \\
\text { Based on my experience, I know the federation service provider is reliable }\end{array}$ & {$[62,156]$} \\
\hline Affective commitment & $\begin{array}{l}\text { I do feel "emotionally attached" to my federation } \\
\text { I was proud to be able to participate in my federation }\end{array}$ & $\begin{array}{l}{[110,118]} \\
{[85]}\end{array}$ \\
\hline Conative commitment & $\begin{array}{l}\text { If I am given a chance, I intend to continue making my service in my federation } \\
\text { I consider the federation service to be my first choice }\end{array}$ & [104] \\
\hline Cognitive commitment & $\begin{array}{l}\text { I'm motivated to maintain the relationship into the future } \\
\text { The relationship will remain intact well into the future }\end{array}$ & $\begin{array}{c}{[108]} \\
{[109,111]}\end{array}$ \\
\hline
\end{tabular}

\subsection{Statistical Analysis}

Partial least squares (PLS), a structural equation-modeling (SEM) tool, is used to perform the analyses. If the objective is theoretical development, PLS-SEM is the appropriate choice [193]. SEM enables researchers to examine the structural component (path model) and measurement component (factor model) simultaneously in one model [156]. One of the most important results is that it allows forecasting of the different latent variables and formative models. PLS is a variance-based technique which is often considered more appropriate than covariance-based modeling techniques when the emphasis is to develop a new model, because PLS is the more flexible method. Every parameter has a predictive interpretation in a simultaneous equation-modeling, and we can use this to discover the level of different karate federations through the latent variables results. To avoid the weaknesses in the estimation of structural equation models, the PLS-Path Modeling Method (PLS-PM) structure is used in which each part of the model needs to be validated: the measurement model, the structural model and the overall model [194]. Also, the consistent PLS (PLSc) algorithm that performs a correction of reflective constructs' correlations was used to ensure that the results were consistent with a factor model. The results are very similar, and it was not necessary to apply this algorithm [195]. 
Table 4. Sample information.

\begin{tabular}{ccc}
\hline Gender & $\%$ & Total $\mathbf{6 2 9}$ \\
\hline Male & 70.7 & 445 \\
Female & 28.9 & 182 \\
Non-responded & 0.3 & 2 \\
\hline Age & $\%$ & Total 629 \\
\hline Less than 16 & 19.6 & 123 \\
$16-29$ & 26.4 & 166 \\
$30-44$ & 18.9 & 119 \\
$45-64$ & 32.4 & 204 \\
More than 64 & 2.5 & 16 \\
Non-responded & 0.2 & 1 \\
\hline Years of Membership & $\%$ & Total $\mathbf{6 2 9}$ \\
\hline Less than 1 & 4.0 & 25 \\
$1-5$ & 15.7 & 99 \\
6-10 & 23.2 & 146 \\
11-20 & 24.3 & 153 \\
More than 20 & 32.6 & 205 \\
Non-responded & 0.2 & 1 \\
\hline Member's Main Activities & $\%$ & Total 629 \\
\hline Courses & 57.6 & 362 \\
Training sessions & 52.6 & 331 \\
Competitions & 49.4 & 311 \\
Exams & 41.5 & 261 \\
Others & 12.6 & 57 \\
None & 9.1 &
\end{tabular}

\section{Results}

\subsection{Measurement Model: Reliability and Validity}

The measurement model in PLS is assessed in terms of inter-construct correlations, item-to-construct correlations, Cronbach's alphas, composite reliabilities, and the Average Variance Extracted (AVE) for each construct. In our seven distinct latent constructs, each of the scales consists of reflective items. In the following paragraphs, we assess the measure's reliability, internal consistency, and discriminant validity for each of the components.

To assess a measure's reliability, we examined how each item relates to the latent constructs. Using the rule of thumb of accepting items with loadings of 0.707 or more, we observed that none of the 21 items failed to reach this level of acceptable reliability. All the loadings exceed 0.78 for these items, and load more highly on their own construct than on others. These results provide strong support for the reliability of the reflective measures (see Table 5).

Internal consistency is assessed using two measures: Cronbach's alpha and composite reliability. Hair, Ringle, and Sarstedt [196] suggest 0.70 as a benchmark for a "modest" reliability applicable in early stages of research and 0.80 as a "stricter" reliability applicable in basic research. As shown in Table 10, both the alpha and composite reliability of each set of reflective measures for each component, as well as each of the other measures included in the study, exceed 0.80 (except for the conative commitment dimension).

Discriminant validity was assessed in two ways. First, we examined AVE, which indicates the amount of variance that is captured by the construct in relation to the variance due to measurement error. Values for AVE should exceed 0.50 [197]. As the statistics presented in Table 10 indicate, all AVE values are greater than this value. Second, we compared the square root of AVE (i.e., the diagonal in Table 6) with the correlations among constructs (i.e., the off-diagonal elements in Table 6). The square root of AVE for all the reflective constructs exceeds 0.5 (see Table 7 ), and each is greater than the correlation between the constructs; to demonstrate discriminant validity, diagonal elements should be 
greater than off-diagonal elements [197]. "Discriminant validity is assessed by comparing the shared variance (squared correlation) between each pair of constructs against the average of the AVEs for these two constructs" [198,199]. These statistics suggest that each construct relates more strongly to its own measures than to measures of other constructs; that is, all the constructs share more variance with their own measures than with the others. These two sets of findings provide strong evidence of discriminant validity among the constructs.

Table 5. Construct, Weights, and Loadings.

\begin{tabular}{cccccc}
\hline Construct & Indicator & Loading & Weight & Mean & St Dev \\
\hline \multirow{2}{*}{ Cognitive Commitment } & Cogcom 01 & 0.927 & 0.523 & 4.245 & 1.137 \\
& Cogcom 02 & 0.935 & 0.551 & 4.141 & 1.131 \\
\hline \multirow{2}{*}{ Conative Commitment } & Concom 01 & 0.909 & 0.543 & 4.349 & 0.983 \\
& Concom 02 & 0.913 & 0.555 & 4.099 & 1.083 \\
\hline \multirow{2}{*}{ Affective Commitment } & Afcom 01 & 0.938 & 0.513 & 3.571 & 1.315 \\
& Afcom 02 & 0.946 & 0.549 & 3.839 & 1.262 \\
\hline \multirow{3}{*}{ Loyalty } & Loy 01 & 0.866 & 0.356 & 4.484 & 0.885 \\
& Loy 02 & 0.925 & 0.415 & 4.220 & 1.084 \\
& Loy 03 & 0.865 & 0.356 & 4.123 & 1.142 \\
\hline \multirow{3}{*}{ Service Quality } & Qual 01 & 0.882 & 0.230 & 3.901 & 1.160 \\
& Qual 02 & 0.904 & 0.240 & 3.990 & 1.144 \\
& Qual 03 & 0.793 & 0.208 & 3.958 & 1.202 \\
& Qual 04 & 0.842 & 0.222 & 4.045 & 1.152 \\
& Qual 05 & 0.909 & 0.251 & 4.016 & 1.099 \\
\hline \multirow{2}{*}{ Satisfaction } & Satis 01 & 0.781 & 0.303 & 4.585 & 0.803 \\
& Satis 02 & 0.926 & 0.426 & 4.204 & 1.104 \\
& Satis 03 & 0.884 & 0.417 & 3.915 & 1.165 \\
\hline \multirow{2}{*}{ Trust } & Trust 01 & 0.914 & 0.269 & 3.933 & 1.159 \\
& Trust 02 & 0.940 & 0.275 & 3.944 & 1.201 \\
& Trust 03 & 0.933 & 0.261 & 3.793 & 1.270 \\
& Trust 04 & 0.942 & 0.267 & 3.792 & 1.249 \\
\hline
\end{tabular}

Table 6. Correlation and square root of the AVE of first Order Latent Construct.

\begin{tabular}{|c|c|c|c|c|c|c|c|}
\hline & $\begin{array}{c}\text { Affective } \\
\text { Commitment }\end{array}$ & $\begin{array}{c}\text { Cognitive } \\
\text { Commitment }\end{array}$ & $\begin{array}{c}\text { Conative } \\
\text { Commitment }\end{array}$ & Loyalty & Service Quality & Satisfaction & Trust \\
\hline $\begin{array}{c}\text { Affective } \\
\text { Commitment }\end{array}$ & 0.942 & & & & & & \\
\hline $\begin{array}{l}\text { Cognitive } \\
\text { Commitment }\end{array}$ & 0.710 & 0.931 & & & & & \\
\hline $\begin{array}{c}\text { Conative } \\
\text { Commitment }\end{array}$ & 0.694 & 0.780 & 0.911 & & & & \\
\hline Loyalty & 0.701 & 0.854 & 0.777 & 0.886 & & & \\
\hline Service Quality & 0.727 & 0.750 & 0.752 & 0.777 & 0.867 & & \\
\hline Satisfaction & 0.729 & 0.820 & 0.743 & 0.832 & 0.830 & 0.866 & \\
\hline Trust & 0.741 & 0.737 & 0.710 & 0.748 & 0.901 & 0.806 & 0.932 \\
\hline
\end{tabular}


Table 7. Internal consistency and AVE.

\begin{tabular}{ccccc}
\hline & Cronbach's Alpha & rho A & $\begin{array}{l}\text { Composite } \\
\text { Reliability }\end{array}$ & Average Variance Extracted (AVE) \\
\hline Affective Commitment & 0.872 & 0.875 & 0.940 & 0.887 \\
Cognitive Commitment & 0.655 & 0.845 & 0.807 & 0.611 \\
Conative Commitment & 0.796 & 0.796 & 0.907 & 0.830 \\
Loyalty & 0.862 & 0.871 & 0.916 & 0.784 \\
Service Quality & 0.917 & 0.921 & 0.938 & 0.752 \\
Satisfaction & 0.832 & 0.861 & 0.899 & 0.749 \\
Trust & 0.950 & 0.950 & 0.964 & 0.869 \\
\hline
\end{tabular}

The research design process attempted to resolve the possible problem of common method bias-which describes the measurement error that is compounded by the sociability of respondents who want to provide positive answers [200] — by applying the procedure recommended by Bove et al. [201]. In addition, a collinearity test based on variance inflation factors (VIF) was applied to detect possible biases in the common method. The occurrence of a VIF greater than 3.3 is proposed as an indication of pathological collinearity, and as an indication that a model may be contaminated by common method bias. All VIFs resulting from the full collinearity test are lower than 3.3, so the model can be considered free of common method bias [202].

\subsection{Structural Model: Goodness of Fit Statistics}

A model estimated through PLS algorithms can only be analyzed if it is placed within a larger model that incorporates consequences of the latent variable in question. According to our model statistics, our index explains a relatively large amount of variance in loyalty; the model's R2 values, the main criteria by which model fit is assessed in PLS analysis [203], are $0.8,0.69,0.81,0.53,0.57$ and 0.56 for loyalty, satisfaction, trust, affective, conative, and cognitive commitment, respectively. In addition, the Stone-Geisser statistic (Q2) gives values greater than zero that indicate that the model has predictive relevance (Table 8 ).

Table 8. R square and Stone-Geisser.

\begin{tabular}{ccc}
\hline Construct & R2 & Q2 \\
\hline Loyalty & 0.798 & 0.587 \\
Satisfaction & 0.688 & 0.482 \\
Trust & 0.811 & 0.662 \\
Affective commitment & 0.529 & 0.488 \\
Conative commitment & 0.566 & 0.450 \\
Cognitive commitment & 0.563 & 0.467 \\
\hline
\end{tabular}

To provide evidence of external validity, loyalty in karate federations should be significantly correlated with other constructs that theory suggests should be associated with the construct [204]. As indicated earlier and depicted in Figure 1, we included other constructs in the study (namely satisfaction, trust, affective, conative, and cognitive commitment) that theory suggests should be related to loyalty. Consistent with the literature, we estimated a model in which these constructs, as antecedents, have a positive relationship with loyalty (see Figure 2 and Table 9). 


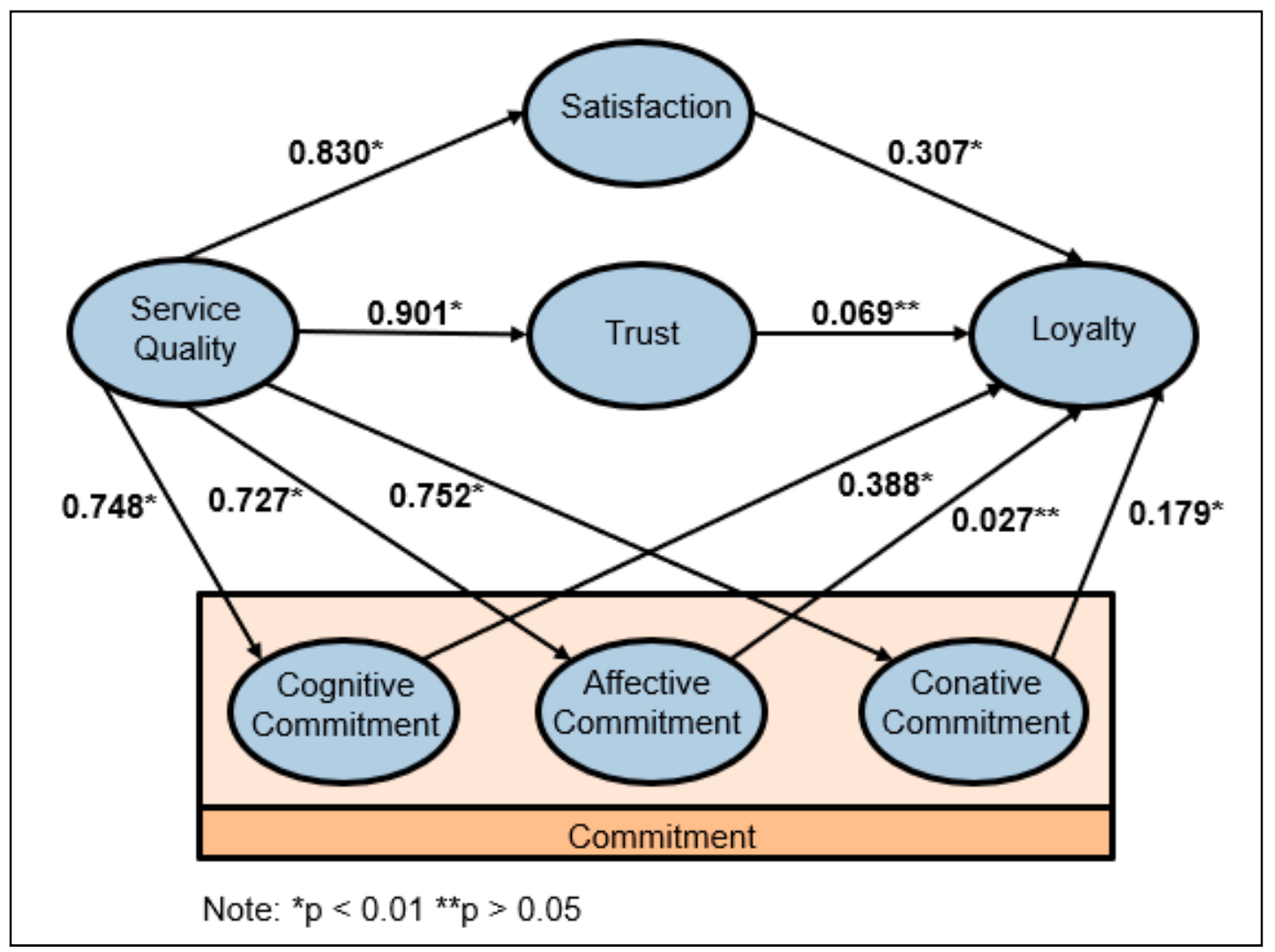

Figure 2. Result.

Table 9. Direct and Indirect Path Coefficients.

\begin{tabular}{ccc}
\hline & Direct Effects & Indirect Effects \\
\hline Service Quality > Satisfaction & $0.830^{* *}$ & \\
Service Quality > Trust & $0.901^{* *}$ & \\
Service Quality > Affective commitment & $0.727^{* *}$ & $0.752^{* *}$ \\
Service Quality > Conative commitment & $0.748^{* *}$ & \\
Service Quality > Cognitive commitment & $0.307^{* *}$ & $0.069^{*}$ \\
Satisfaction > Loyalty & $0.027^{*}$ & $0.680 * *$ \\
Trust $>$ Loyalty & $0.179^{* *}$ & \\
Affective commitment $>$ Loyalty & $0.388^{* *}$ & \\
Conative commitment > Loyalty & & \\
Cognitive commitment > Loyalty & Service Quality > Loyalty &
\end{tabular}

\subsection{Results of SEM}

Figure 2 and Table 9 show the indirect and direct effects between latent variables. This Figure indicates significant and non-significant path coefficients (at $p<0.001$ ) because both trust and affective commitment have non-significant path coefficients. The significance of the paths was estimated using a PLS bootstrapping procedure using 5000 resamples, an amount that provides reasonable standard error estimates [205].

One of the first results of this research is the existence (across various variables) of a relationship between service quality and loyalty. We find an important, though indirect relationship (0.68), especially if we take into account the current difficulty of influencing loyalty with a variable other than satisfaction (with an important relationship in this case of 0.307). Thus, service quality seems to be an important element that influences loyalty, but mainly through satisfaction and cognitive commitment, with the significant managerial consequences that this implies. All dimensions have a strong relationship with service 
quality but only satisfaction (0.30) and cognitive commitment (0.39) maintain a relatively important relationship with loyalty.

The total effect of service quality on loyalty through commitment dimensions, trust and satisfaction is the main focus of this study. The results help to determine the verification of the various hypotheses detailed in the theorical section. All hypotheses are supported but are rejected. All relationships are significant and have at least a moderate and positive influence, and only affective commitment influence on loyalty and trust influence on loyalty showed irrelevant relationships (see Table 10).

Table 10. Summary of hypothesis verification.

\begin{tabular}{|c|c|c|}
\hline Hypothesis & Content & Verification \\
\hline $\mathrm{H} 1$ & Service quality influences positively on satisfaction of federated sportspeople & Supported \\
\hline $\mathrm{H} 2$ & Service quality influences positively on trust of federated sportspeople & Supported \\
\hline $\mathrm{H} 3 \mathrm{a}$ & Service quality influences positively on cognitive commitment of federated sportspeople & Supported \\
\hline $\mathrm{H} 3 \mathrm{~b}$ & Service quality influences positively on affective commitment of federated sportspeople & Supported \\
\hline $\mathrm{H} 3 \mathrm{c}$ & Service quality influences positively on conative commitment of federated sportspeople & Supported \\
\hline $\mathrm{H} 4$ & Satisfaction influences positively on loyalty of federated sportspeople & Supported \\
\hline H5 & Trust influences positively on loyalty of federated sportspeople & Rejected \\
\hline H6a & Cognitive commitment influences positively on loyalty of federated sportspeople & Supported \\
\hline $\mathrm{H} 6 \mathrm{~b}$ & Affective commitment influences positively on loyalty of federated sportspeople & Rejected \\
\hline $\mathrm{H} 6 \mathrm{c}$ & Conative commitment positively on loyalty of federated sportspeople & Supported \\
\hline
\end{tabular}

\section{Discussion and Conclusions}

\subsection{Theoretical Implications}

This research investigated whether service quality can be an antecedent of loyalty through commitment dimensions, trust and satisfaction. The idea was to attempt to explain how Spanish federations can create a sustainable model for developing service quality to gain loyal "consumers". The data gathered from Spanish karate federations suggest that although trust and affective commitment are not relevant mediators in determining consumers' attitudes toward loyalty, satisfaction, and cognitive and conative commitment contribute to making service quality a strong factor in increasing loyalty in sport organizations $[145,178,192]$. First, the results from the sample suggest that service quality is a strong antecedent of trust, satisfaction and commitment dimensions as the literature indicates [31,81]. The strongest effect of service quality is on trust. This is very likely because trust in an organization is based on the consumer's certainty of the quality and integrity of the service offered $[81,82,85]$ and sport federations are no exception to this [89]. The second strongest effect is on satisfaction, as a few recent studies on sport organizations confirm [41,54]. Finally, service quality in Spanish karate federations shows a relevant influence on all commitment dimensions, as expected, because commitment-together with trust-is the most commonly accepted variable in perceived quality models $[74,81,82,84]$, and even in sport organizations service quality has been used as a relevant construct to explain commitment [89,92,95-98].

Service quality value must be translated its increasing to loyalty through satisfaction, cognitive, and conative commitment. It is observed in most of the theory that satisfaction is a mediating channel between perceived quality and loyalty $[65,206,207]$. Satisfaction is the most common antecedent of loyalty and there is an extensive literature that links the two variables in sport organizations [144,147]. In fact, the literature has come to regard satisfaction as a measure of loyalty. However, in the case of federations, satisfaction does not influence whether consumers have a loyal attitude and can represent significant loyal behavior [208], and the loyalty variable is built on both dimensions. This may be why the relationship between these variables is only relevant and it is not a very strong [130]. Meanwhile, the result of the relationship between loyalty and conative and cognitive commitment is closer to what has been stated in the theory $[62,128,209,210]$, even in sports organization studies where some papers show only a weak influence of conative com- 
mitment [191,192] and a strong influence of cognitive commitment [178]. Finally, trust and affective commitment cannot constitute useful mediators between service quality and loyalty. Members of Spanish karate federations seem to be more motivated by their own sporting objectives than by the efforts of federations' management to gain their trust. The assumption that trust might be more important when services are characterized primarily by credence and/or experience qualities and less important in consumer decisions dominated by search qualities (as in the case of federations) may form part of the explanation of the irrelevant relationship between trust and loyalty [211]. On the other hand, loyalty of federation members is based on rational elements because the emotional component is likely to be linked to the sport they practice and not so much to the management or service they receive from federations [130].

\subsection{Managerial Implications}

Loyalty is a crucial element in maintaining relationships over time, and thus an element on which marketing managers must focus [165]. Non-profit organizations have not been very enthusiastic about the idea of using the tools offered by marketing in the past because they wish to avoid being identified with for-profit organizations [212]. However, it is true that prejudices against marketing are weaker than before, since many federations do now use marketing tools. However, it is also true that smaller growth rates in federations than in the sport industry could be motivated by a few ambitions for growing in these kinds of non-profit sport organizations.

Sports federation members are an important consumer group in Spain; however, this group has not grown significantly over recent years. If federations aim to be competitive, they must change their strategy and acquire in-depth knowledge of their current and potential clients $[5,11,213]$. It is, therefore, very important to make a detailed study of the variables that influence the loyalty of a federation member.

Based on the results obtained empirically from the questionnaire completed by Spain's karate federation members, federations should pay attention to satisfaction and cognitive commitment. They should be aware that both variables start from, or are quite considerably influenced by, perceived quality. Federation directors should focus their strategies on perceived quality, and this is the area where they can act most effectively.

Karate federation directors should plan strategies that increase service quality as perceived by sportspeople so that federation members are satisfied with the services provided; the relationship between these two variables is so logical that they are difficult to separate in practice. In fact, in practically all fields, perceived quality influences satisfaction $[65,206,214-216]$.

Since, of the three dimensions, it is cognitive commitment that has the greatest influence on loyalty, we can assume that for karate federation members, it is the practical and rational factors that have the greatest weight. The actions taken by federation directors must therefore take into account the most practical and rational aspects of quality, such as a cost appropriate to the service provided; facilities in good condition; and courses and activities that are efficiently organized $[107,108]$.

If cognitive commitment encompasses the more practical part of being a sportsperson, the satisfaction variable is more closely linked to the affective dimension. For quality to have a greater influence on satisfaction, the environment provided by the federation should be improved, as well as the efficiency and people skills of the federation's employees. Efficient organization of the federation's various activities should also be a priority, because this will influence satisfaction as well as cognitive commitment.

Conative commitment is not the most relevant mediator between service quality and loyalty, but it is advisable to work to develop some activities that reward those members that show a commitment to their federation. Conative commitment could become more relevant if this kind of reward system were more usual.

Additionally, since federations are non-profit organizations whose final objective is not financial profit and sustainable organizations but rather to promote the practice of their 
sports, loyalty is, in itself, an end for these organizations. Creating strategies aimed at maximizing service quality should be their reason for being.

\subsection{Limitations and Future Research}

Federations should combine their efforts to provide services of the highest quality; however, even when this may already be their intention, in practice directors find that resources are limited and, on many occasions, federation fees are not a sufficient source of income. Achieving a large membership may result in higher incomes, making it possible to improve service quality [217].

One of the objectives of this study was to provide an example of an explanatory model of loyalty for federations; to fulfil this aim it is necessary to broaden the field of research, carrying out a multidisciplinary study that would include several sports as opposed to focusing on federations in a specific discipline. Our future lines of research are orientated in that direction, and it would be desirable to work towards extending this study to the national level, and even extrapolate it to other countries.

Author Contributions: Conceptualization, P.C.-V., P.G.-R. and C.L.-V.; methodology, P.C.-V., P.G.-R. and C.L.-V.; software, P.C.-V., P.G.-R. and C.L.-V.; validation, P.C.-V., P.G.-R. and C.L.-V.; formal analysis, P.C.-V., P.G.-R. and C.L.-V.; investigation, P.C-V., P.G.-R. and C.L.-V.; resources, P.C.-V., P.G.-R. and C.L.-V.; writing—original draft preparation, P.C.-V., P.G.-R. and C.L.-V.; writing-review and editing, P.C.-V., P.G.-R. and C.L.-V.; visualization, P.C.-V., P.G.-R. and C.L.-V.; supervision, P.C.-V., P.G.-R. and C.L.-V. All authors have read and agreed to the published version of the manuscript.

Funding: This research received no external funding.

Institutional Review Board Statement: Not applicable.

Informed Consent Statement: Not applicable.

Data Availability Statement: Not applicable.

Acknowledgments: The authors are grateful to the 19 Spanish Regional Karate Federations for sharing their data on satisfaction and loyalty from sportspeople who are licensed members of sports federations in Spain.

Conflicts of Interest: The authors declare no conflict of interest.

\section{References}

1. Winand, M.; Scheerder, J.; Vos, S.; Zintz, T. Do non-profit sport organisations innovate? Types and preferences of service innovation within regional sport federations. Innovation 2016, 18, 289-308. [CrossRef]

2. Kim, C.; Kaplanidou, K. The effect of sport involvement on support for mega sport events: Why does it matter. Sustainability 2019, 11, 5687. [CrossRef]

3. Winand, M.; Zintz, T.; Scheerder, J. A financial management tool for sport federations. Int. J. Sport Bus. Manag. 2012, 2, 225-240. [CrossRef]

4. Chen, G.; Zhang, J.J.; Pifer, N.D. Corporate governance structure, financial capability, and the R \& D intensity in Chinese sports sector: Evidence from listed sports companies. Sustainability 2019, 11, 6810. [CrossRef]

5. Mirvis, P.H.; Sales, A.L.; Hackett, E.J. The implementation and adoption of new technology in organizations: The impact on work, people, and culture. Hum. Resour. Manag. 1991, 30, 113-139. [CrossRef]

6. Smith, D.H. Grassroots Associations; Sage: Thousand Oaks, CA, USA, 2000.

7. Leśniewska, A.; Stosik, A.; Łasiński, G. The effectiveness of the Polish Sport Federations in athletes' opinion. J Posit. Manag. 2018, 9, 34-55. [CrossRef]

8. Parra-Camacho, D.; Alguacil, M.; Calabuig-Moreno, F. Perception of the fair social distribution of benefits and costs of a sports event: An analysis of the mediating effect between perceived impacts and future intentions. Sustainability 2020, $12,4413$. [CrossRef]

9. Fullerton, S.; Merz, G.R. The four domains of sports marketing: A conceptual framework. Sport Mark. Q. 2008, 17, 90-108.

10. Consejo Superior de Deportes. Deporte de Alto Nivel y Alto Rendimiento. Available online: https://www.csd.gob.es/es/altacompeticion/deporte-de-alto-nivel-y-alto-rendimiento (accessed on 18 November 2020).

11. Wemmer, F.; Koenigstorfer, J. Open Innovation in Nonprofit Sports Clubs. Int. J. Volunt. Nonprofit Organ. 2016, 27, 1923-1949. [CrossRef]

12. Smith, A.; Stewart, B. The special features of sport: A critical revisit. Sport Manag. Rev. 2010, 13, 1-13. [CrossRef] 
13. Sargeant, A.; Woodliffe, L. Building donor loyalty: The antecedents and role of commitment in the context of charity giving. J. Nonprofit Public Sect. Mark. 2007, 18, 1-33. [CrossRef]

14. Kotler, P. Social marketing: An approach to planned social change. J. Mark. 1971, 35, 3-12. [CrossRef] [PubMed]

15. Loranca-Valle, C.; Cuesta-Valiño, P.; Barriopedro-Núñez, E. Análisis del grado de felicidad del deportista federado en karate en España en función de sus características demográficas. In La Brújula del Siglo XXI: El Happiness Management. Un Concepto A Explotar por las Empresas, el Marketing Social y el Liderazgo Organizacional; Ravina Ripoll, R., Bayardo Tobar Pesantez, L., Núñez Barriopedro, E., Galiano Coronil, A., Eds.; Tiran Lo Blanch: Valencia, Spain, 2020; pp. 83-102.

16. Breuer, C.; Feiler, S.; Llopis-Goig, R.; Elmose-Østerlund, K.; Bürgi, R.; Claes, E.; Gebert, A.; Ibsen, B.; Nagel, S.; Nichols, G.; et al. Characteristics of European Sports Clubs. A Comparison of the Structure, Management, Voluntary Work and Social Integration Among Sports Clubs Across Ten European Countries; University of Southern Denmark: Odense, Denmark, 2017.

17. Breuer, C.; Hoekman, R.; Nagel, S.; van der Werff, H. Sport Clubs in Europe; Springer: Heidelberg, Germany, 2015. [CrossRef]

18. Breuer, C.; Swierzy, P.; Feiler, S. Sport clubs in Europe: Organization. In The SAGE Handbook of Sports Economics; Downward, P., Frick, B., Humphreys, B.R., Pawlowski, T., Ruseskt, J.E., Soebbing, B.P., Eds.; SAGE: New York, NY, USA, 2019.

19. Ministerio de Cultura y Deporte. Anuario de Estadísticas Deportivas 2020. Available online: https:/ / www.culturaydeporte.gob. es/dam/jcr:47414879-4f95-4cae-80c4-e289b3fbced9/anuario-de-estadisticas-deportivas-2020.pdf (accessed on 22 October 2020).

20. Consejo Superior de Deportes. Página Oficial del Consejo Superior de Deportes. Available online: https://www.csd.gob.es/es/ csd (accessed on 29 December 2020).

21. Real Federación Española de Kárate y Disciplinas Asociadas. Available online: http://www.rfek.es/ (accessed on 29 December 2020).

22. Olympic. Welcome to the Spectacular World of Karate. Available online: https://www.olympic.org/news/welcome-to-theworld-of-karate (accessed on 22 October 2020).

23. Zeithaml, V.A. Consumer perceptions a means-end value: Quality, and model synthesis of evidence. J. Mark. 1988, 52, 2-22. [CrossRef]

24. Parasuraman, A.; Zeithaml, V.A.; Berry, L.L. SERVQUAl: A multiple-item scale for measuring consumer perc. J. Retail. 1988, 64, 12-28.

25. Parasuraman, A.; Zeithaml, V.A.; Berry, L.L. A conceptual model of service quality and its implications for future research. J. Mark. 1985, 49, 41-50. [CrossRef]

26. Butt, M.M.; de Run, E.C. Private healthcare quality: Applying a SERVQUAL model. Int. J. Health Care Qual. Assur. 2010, 23, 658-673. [CrossRef]

27. Farooq, M.; Khalil, F.; Tijjani, D.; Younas, W.; Sajjad, S.; Zreen, A. Service quality analysis of private universities libraries in Malaysia. Int. J. Qual. Res. 2019, 13, 269-284. [CrossRef]

28. Gilbert, D.; Wong, R.K. Passenger expectations and airline services: A Hong Kong based study. Tour. Manag. 2003, 24, 519-532. [CrossRef]

29. Lee-Ross, D. An exploratory study of the contextual stability of SERVQUAL amongst three retail clusters in far North Queensland. J. Place Manag. Dev. 2008, 1, 46-61. [CrossRef]

30. Samen, A.A.A.; Akroush, M.N.; Abu-Lail, B.N. Mobile SERVQUAL: A comparative analysis of customers' and managers' perceptions. Int. J. Qual. Reliab. Manag 2013, 30, 403-425. [CrossRef]

31. Farooq, M.S.; Salam, M.; Fayolle, A.; Jaafar, N.; Ayupp, K. Impact of service quality on customer satisfaction in Malaysia airlines: A PLS-SEM approach. J. Air Transp. Manag. 2018. [CrossRef]

32. Buttle, F. SERVQUAL: Review, critique, research agenda. Eur. J. Mark. 1996, 30, 8-32. [CrossRef]

33. Cronin, J.J.; Taylor, S.A. Measuring service quality: A reexamination and extension. J. Mark. 1992, 3, 55-68. [CrossRef]

34. Robledo, M.A. Measuring and managing service quality: Integrating customer expectations. Int. J. Manag. Serv. Qual. 2001, 11, 22-31. [CrossRef]

35. Cronin, J.J.; Taylor, S.A. SERVPERF versus SERVQUAL: Reconciling performance-based and perceptions-minus-expectations measurement of service quality. J. Mark. 1994, 58, 125-131. [CrossRef]

36. Chang, Y.H.; Yeh, C.H. A survey analysis of service quality for domestic airlines. Eur. J. Oper. Res. 2002, 139, 166-177. [CrossRef]

37. Chen, C.F.; Chen, F.S. Experience quality, perceived value, satisfaction and behavioral intentions for heritage tourists. Tour. Manag. 2010, 31, 29-35. [CrossRef]

38. Lai, W.T.; Chen, C.F. Behavioral intentions of public transit passengers-The roles of service quality, perceived value, satisfaction and involvement. Transp. Policy 2011, 18, 318-325. [CrossRef]

39. Meesala, A.; Paul, J. Service quality, consumer satisfaction and loyalty in hospitals: Thinking for the future. J. Retail. Consum. Serv. 2018, 40, 261-269. [CrossRef]

40. Hult, G.T.M.; Sharma, P.N.; Morgeson, F.V., III; Zhang, Y. Antecedents and consequences of customer satisfaction: Do they differ across online and offline purchases? J. Retail. 2019, 95, 10-23. [CrossRef]

41. García-Fernández, J.; Gálvez-Ruíz, P.; Fernández-Gavira, J.; Vélez-Colón, L.; Pitts, B.; Bernal-García, A. The effects of service convenience and perceived quality on perceived value, satisfaction and loyalty in low-cost fitness centers. Sport Manag. Rev. 2018, 21, 250-262. [CrossRef]

42. Polyakova, O.; Mirza, M.T. Service quality models in the context of the fitness industry. Sport Bus. Manag. Int. J. 2016, 6, 360-382. [CrossRef] 
43. Chang, K.; Chelladurai, P. System-based quality dimensions in fitness services: Development of the scale of quality. Serv. Ind. J. 2003, 23, 65-83. [CrossRef]

44. Kim, D.; Kim, S.Y. QUESC: An instrument for assessing the service quality of sport centers in Korea. J. Sport Manag. 1995, 9 , 208-220. [CrossRef]

45. Brady, M.K.; Cronin, J.J., Jr. Some new thoughts on conceptualizing perceived service quality: A hierarchical approach. J. Mark. 2001, 65, 34-49. [CrossRef]

46. Chelladurai, P.; Chang, K. Targets and standards of quality in sport services. Sport Manag. Rev. 2000, 3, 1-22. [CrossRef]

47. Papadimitriou, D.; Karteliotis, K. The service quality expectations in private sport and fitness centers: A re-examination of the factor structure. Sport Mark. Q. 2000, 9, 157-164.

48. Avourdiadou, S.; Laios, A.; Kosta, G.; Theodorakis, N. The relationship of service quality dimensions with the overall satisfaction among participants from different experience levels. Hell. J. Sport Recreat Manag. 2014, 11, 1-13.

49. Gonçalves, C.; Biscaia, R.; Correia, A.; Diniz, A. An examination of intentions of recommending fitness centers by user members. Motriz J. Phys. Educ. 2014, 20, 384-391. [CrossRef]

50. Garcia-Fernandez, J.; Sanchez-Oliver, A.; Grimaldi-Puyana, M.; Fernandez-Gavira, J.; Galvez-Ruiz, P. Quality and customer loyalty: A segmentation analysis in low-cost fitness centers. Rev. Psicol. Deporte 2017, 26, 17-22. [CrossRef]

51. Clemes, M.D.; Brush, G.J.; Collins, M.J. Analysing the professional sport experience: A hierarchical approach. Sport Manag. Rev. 2011, 14, 370-388. [CrossRef]

52. Foroughi, B.; Iranmanesh, M.; Gholipour, H.F.; Hyun, S.S. Examining relationships among process quality, outcome quality, delight, satisfaction and behavioural intentions in fitness centres in Malaysia. J. Sport Mark. Spons. 2019, 20, 374-389. [CrossRef]

53. Theodorakis, N.D.; Howat, G.; Ko, Y.J.; Avourdiadou, S. A comparison of service evaluation models in the context of sport and fitness centres in Greece. Manag. Leis. 2014, 19, 18-35. [CrossRef]

54. Avourdiadou, S.; Theodorakis, N.D. The development of loyalty among novice and experienced customers of sport and fitness centres. Sport Manag. Rev. 2014, 17, 419-431. [CrossRef]

55. Oliver, R.L. A cognitive model of the antecedents and consequences of satisfaction decisions. J. Mark. 1980, 17, 460-469. [CrossRef]

56. Andreassen, T.W. Antecedents to satisfaction with service recovery. Eur. J. Mark. 2000, 34, 156-175. [CrossRef]

57. Maxham, J.G.; Netemeyer, R.G. A longitudinal study of complaining customers' evaluations of multiple service failures and recovery efforts. J. Mark. 2002, 66, 57-71. [CrossRef]

58. Zablah, A.; Carlson, B.; Donavan, T.; Maxham, J.; Brown, T. A cross-lagged test of the association between customer satisfaction and employee job satisfaction in a relational context. J. Appl. Psychol. 2016, 101, 743-755. [CrossRef]

59. Teixeira, J.; Patrício, L.; Nunes, N.J.; Nóbrega, L.; Fisk, R.P.; Constantine, L. Customer experience modeling: From customer experience to service design. J. Serv. Manag. 2012, 23, 362-376. [CrossRef]

60. Moon, H.; Yoon, H.J.; Han, H. Role of airport physical environments in the satisfaction generation process: Mediating the impact of traveller emotion. Asia Pacific. J. Tour. Res. 2016, 21, 193-211. [CrossRef]

61. Li, X.; Petrick, J.F. Towards an integrative model of loyalty formation: The role of quality and value. Leis. Sci. 2010, 32, $201-221$. [CrossRef]

62. Deng, Z.; Lu, Y.; Wei, K.K.; Zhang, J. Understanding customer satisfaction and loyalty: An empirical study of mobile instant messages in China. Int. J. Inf. Manag. 2010, 30, 289-300. [CrossRef]

63. McDougall, G.H.; Levesque, T. Customer satisfaction with services: Putting perceived value into the equation. J. Serv. Mark. 2000, 14, 392-410. [CrossRef]

64. Ryu, K.; Han, H. Influence of the quality of food, service, and physical environment on customer satisfaction and behavioral intention in quick-casual restaurants: Moderating role of perceived price. J. Hosp. Tour. Res. 2010, 34, 310-329. [CrossRef]

65. Su, L.; Swanson, S.R.; Chen, X. The effects of perceived service quality on repurchase intentions and subjective well-being of Chinese tourists: The mediating role of relationship quality. Tour. Manag. 2016, 52, 82-95. [CrossRef]

66. Shin, D.; Kim, W. Forecasting customer switching intention in mobile service: An exploratory study of predictive factors in mobile number portability. Technol. Forecast. Soc. Chang. 2008, 75, 854-874. [CrossRef]

67. Han, X.; Kwortnik, R.; Wang, C. Service loyalty: An integrated model and examination across service contexts. J. Serv. Res. 2008, 11, 22-42. [CrossRef]

68. Calabuig, F.; Prado-Gascó, V.; Crespo, J. Predicting future intentions of basketball spectators using SEM and fsQCA. J. Bus. Res. 2016, 69, 1396-1400. [CrossRef]

69. Garcia Fernandez, J.; Cepeda Carrion, G.; Martin Ruiz, D. Customer satisfaction and its relation to perceived quality in fitness centres: Calidfit scale. Rev. Psicol. Deporte 2012, 21, 309-319.

70. García-Fernández, J.; Gálvez-Ruiz, P.; Fernández-Gavira, J.; Vélez-Colon, L. A loyalty model according to membership longevity of low-cost fitness center: Quality, value, satisfaction, and behavioral intention. J. Sport Psychol. 2016, 25, 107-110.

71. García-Fernández, J.; Gálvez-Ruiz, P.; Vélez-Colon, L.; Bernal-García, A. Antecedents of customer loyalty: A case of low-cost fitness centers. In Contemporary Sport Marketing: Global Perspectives; Zhang, J.J., Pitts, B.G., Eds.; Routledge Publishers: Oxfordshire, UK, 2017; pp. 139-155.

72. Das, T.K.; Teng, B.S. The risk-based view of trust: A conceptual framework. J. Bus. Psychol. 2004, 19, 85-116. [CrossRef]

73. Berry, L. Relationship marketing of services growing interest, emerging perspectives. J. Acad. Mark. Sci. 1995, 23, 236-245. [CrossRef] 
74. Dwyer, F.R.; Schurr, P.H.; Oh, S. Developing Buyer-Seller Relationships. J. Mark. 1987, 51, 11-27. [CrossRef]

75. Anderson, E.; Weitz, B. Determinants of continuity in conventional industrial channel dyads. Mark. Sci. 1989, 8, 310-323. [CrossRef]

76. Mayer, R.C.; Davis, J.H.; Schoorman, F.D. An integrative model of organizational trust. Acad. Manag. Rev. 1995, 20, 709-734. [CrossRef]

77. Anderson, J.C.; Narus, J.A. A model of distributor firm and manufacturer firm working partnerships. J. Mark. 1990, 54, 42-58. [CrossRef]

78. Covey, S.R.; Merrill, R.R. The Speed of Trust: The One Thing That Changes Everything; Simon and Schuster: New York, NY, USA, 2006.

79. Józefowicz, B. Trust in creating pro-developmental positive organisational potential outcomes. In Positive Management: Managing the Key Areas of Positive Organisational Potential for Company Success; Stankiewicz, M.J., Ed.; Dom Organizatora TNOiK: Toruń, Poland, 2013; pp. 155-178.

80. Christiansen, T.; DeVaney, S.A. Antecedents of trust and commitment in the financial planner-client relationship. Financ. Couns. Plan. 1998, 9, 1-10.

81. Morgan, R.M.; Hunt, S.D. The commitment-trust theory of relationship marketing. J. Mark. 1994, 58, 20-38. [CrossRef]

82. Palmatier, R.; Grewal, D.; Evans, K. Factors influencing the effectiveness of relationship marketing: A meta-analysis. J. Mark. 2006, 70, 136-153. [CrossRef]

83. Fournier, S. Consumers and their brands: Developing relationship theory in consumer research. J. Consum. Res. 1998, 24, 343-373. [CrossRef]

84. Garbarino, E.; Johnsonm, M.S. The different roles of satisfaction, trust, and commitment in customer relationships. J. Mark. 1999, 63, 70-87. [CrossRef]

85. Hennig-Thurau, T.; Langer, M.F.; Hansen, U. Modeling and managing student loyalty: An approach based on the concept of relationship quality. J. Serv. Res. 2001, 3, 331-344. [CrossRef]

86. Konuk, F.A. The role of store image; perceived quality, trust and perceived value in predicting consumers' purchase intentions towards organic private label food. J. Retail. Consum. Serv. 2018, 43, 304-310. [CrossRef]

87. Aurier, P.; de Lanauze, G.S. Impacts of perceived brand relationship orientation on attitudinal loyalty. Eur. J. Mark. 2012, 46, 1602-1627. [CrossRef]

88. Kim, Y.K.; Trail, G. A conceptual framework for understanding relationships between sport consumers and sport organizations: A relationship quality approach. J. Sport Manag. 2011, 25, 57-70. [CrossRef]

89. Kim, Y.K.; Trail, G.; Ko, Y.J. The influence of relationship quality on sport consumption behaviors: An empirical examination of the relationship quality framework. J. Sport Manag. 2011, 25, 576-592. [CrossRef]

90. Geyskens, I.; Steenkamp, J.E.M.; Scheer, L.K.; Kumar, N. The effects of trust and interdependence on relationship commitment: A trans-Atlantic study. Int. J. Res. Mark. 1996, 13, 303-317. [CrossRef]

91. de Ruyter, K.; Wetzels, M.; Bloemer, J. On the relationship between perceived service quality, service loyalty and switching costs. Int. J. Serv. Ind. Manag. 1998, 9, 436-453. [CrossRef]

92. Mahony, D.F.; Madrigal, R.; Howard, D.A. Using the psychological commitment to team (PCT) scale to segment sport consumers based on loyalty. Sport Mark. Q. 2000, 9, 15.

93. Rather, R.A. Investigating the impact of customer brand identification on hospitality brand loyalty: A social identity perspective. J. Hosp. Mark. Manag. 2018, 27, 487-513. [CrossRef]

94. Ross, S.; James, J.; Vargas, P. Development of a scale to measure team brand associations in professional sport. J. Sport Manag. 2006, 20, 260-279. [CrossRef]

95. Funk, D.C.; James, J. The psychological continuum model: A conceptual framework for understanding an individual's psychological connection to sport. Sport Manag. Rev. 2001, 4, 119-150. [CrossRef]

96. Funk, D.C.; Pritchard, M.P. Sport publicity: Commitment's moderation of message effects. J. Bus. Res. 2006, 59, 613-621. [CrossRef]

97. Giovanis, A.N.; Athanasopoulou, P. Consumer-brand relationships and brand loyalty in technology-mediated services. J. Retail. Consum. Serv. 2018, 40, 287-294. [CrossRef]

98. Won, K.-J.; Sunhwan, H. Effects of the international tennis event service quality on relation commitment, spectator satisfaction and revisit intention. Korean J. Converg. Sci. 2019, 8, 33-47.

99. Jones, T.; Fox, G.L.; Taylor, S.F.; Fabrigar, L.R. Service customer commitment and response. J. Serv. Mark. 2010, 24, 16-28. [CrossRef]

100. Allen, N.J.; Meyer, J.P. The measurement and antecedents of affective, continuance and normative commitment to the organization. J. Occup. Psychol. 1990, 63, 1-18. [CrossRef]

101. Gruen, T.W.; Summers, J.O.; Acito, F. Relationship marketing activities, commitment, and membership behaviors in professional associations. J. Mark. 2000, 64, 34-49. [CrossRef]

102. Meyer, J.P.; Allen, N.J. A three-component conceptualization of organizational commitment. Hum. Resour. Manag. Rev. 1991, 1, 61-89. [CrossRef]

103. Arriaga, X.; Agnew, C. Being committed: Affective, cognitive, and conative components of relationship commitment. Personal. Soc. Psychol. Bull. 2001, 27, 1190-1203. [CrossRef] 
104. Yuksel, A.; Yuksel, F.; Bilim, Y. Destination attachment: Effects on customer satisfaction and cognitive, affective and conative loyalty. Tour. Manag. 2010, 31, 274-284. [CrossRef]

105. Robbins, S.; Judge, T.A. Organizational Behavior; Pearson: Upper Saddle River, NJ, USA, 2007.

106. Yao, T.; Qiu, Q.; Wei, Y. Retaining hotel employees as internal customers: Effect of organizational commitment on attitudinal and behavioral loyalty of employees. Int. J. Hosp. Manag. 2019, 76, 1-8. [CrossRef]

107. Wiener, Y. Commitment in organizations: A normative view. Acad. Manag. Rev. 1982, 7, 418-428. [CrossRef]

108. Holmes, J.G.; Rempel, J.K. Close relationships. Rev. Personal. Soc. Psychol. 1989, 10, 187-220.

109. Marston, P.J.; Hecht, M.L.; Manke, M.L.; McDaniel, S.; Reeder, H. The subjective experience of intimacy, passion, and commitment in heterosexual loving relationships. J. Int. Assoc. Relatsh. Res. 1998, 5, 15-30. [CrossRef]

110. Meyer, J.P.; Allen, N.J. Commitment in the Workplace: Theory; Research and Application; SAGE: Thousand Oaks, CA, USA, 1997.

111. Miller, G.R.; Boster, F. Persuasion in Personal Relationships; American Psychological Association: Washington, DC, USA, 1988.

112. Gull, S.; Ashraf, S.M. Impact of internal branding on service employees' quality commitment-study on education sector of Pakistan. Int. J. Bus. Soc. Sci. 2012, 3, 302-311.

113. Bae, J.S.; Nam, S.B.; Lee, K.Y. Impact of employee and member empowerment on commitment in Korean sports organizations: A meta-analysis. Soc. Behav. Personal. Int, J. 2020, 48, 1-15. [CrossRef]

114. Mattila, A.S. The impact of service failures on customer loyalty: The moderating role of affective commitment. Int. J. Serv. Ind. Manag. 2004, 15, 134-149. [CrossRef]

115. Clarke, N.; Mahadi, N. The significance of mutual recognition respect in mediating the relationships between trait emotional intelligence, affective commitment and job satisfaction. Personal. Individ. Dif 2017, 105, 129-134. [CrossRef]

116. Perreira, T.; Morin, A.; Hebert, M.; Gillet, N.; Houle, S.; Berta, W. The short form of the workplace affective commitment multidimensional questionnaire (WACMQ-S): A bifactor-ESEM approach among healthcare professionals. J. Vocat. Behav. 2018, 106, 62-83. [CrossRef]

117. Poushneh, A.; Vasquez-Parraga, A.Z. Emotional bonds with technology: The impact of customer readiness on upgrade intention, brand loyalty, and affective commitment through mediation impact of customer value. J. Theor. Appl. Electron. Commer. Res. 2019, 14. [CrossRef]

118. Hur, W.M.; Kim, H.; Kim, H.K. Does customer engagement in corporate social responsibility initiatives lead to customer citizenship behaviour? The mediating roles of customer-company identification and affective commitment. Corp. Soc. Responsib. Environ. Manag. 2018, 25, 1258-1269. [CrossRef]

119. Rhoades, L.; Eisenberger, R.; Armeli, S. Affective commitment to the organization: The contribution of perceived organizational support. J. Appl. Psicol. 2001, 86, 825-836. [CrossRef] [PubMed]

120. Hsiao, C.-H.; Shen, G.; Chao, P.-J. How does brand misconduct affect the brand-customer relationship? J. Bus. Res. 2015, 68, 862-866. [CrossRef]

121. Venetis, K.A.; Ghauri, P.N. Service quality and customer retention: Building long-term relationships. Eur. J. Mark. 2004, 38, 1577-1598. [CrossRef]

122. Xie, D. Exploring Organization Learning Culture, Job Satisfaction, Motivation to Learn, Organizational Commitment, And Internal Service Quality in a Sport Organization; Ohio State University: Columbus, OH, USA, 2005.

123. Markovic, S.; Iglesias, O.; Singh, J.J.; Sierra, V. How does the perceived ethicality of corporate services brands influence loyalty and positive word-of-mouth? Analyzing the roles of empathy, affective commitment, and perceived quality. J. Bus. Ethics 2004, 148, 721-740. [CrossRef]

124. Qanbarpur Nosrati, A.; Saatchian, V.; Soleimani, S.; Ali Soltani Zarandi, H. The relationship between organizational learning culture, motivation for learning and service quality in selected federations. J. Sport. Manag. 2012, 4, 91-107.

125. Hwang, J.; Hyun, S.S. Perceived firm innovativeness in cruise travelers' experience and perceived luxury value: The moderating effect of advertising effectiveness. Asia Pac. J. Tour. Res. 2016, 21, 101-128. [CrossRef]

126. Oppong, P.; Adjei, H.; Poku, K. The role of information technology in building customer loyalty in banking: (A case study of agricultural development bank Ltd.; SUNYANI). Br. J. Mark. Stud. 2014, 2, 9-29.

127. Alexandris, K.; Kouthouris, C.; Meligdis, A. Increasing customers' loyalty in a skiing resort. Int. Contemp. Hosp. Manag. 2006, 18, 414-425. [CrossRef]

128. Oliver, R.L. Whence Consumer Loyalty. J. Mark. 1999, 63, 33-44. [CrossRef]

129. Labeaga, J.M.; Lado, N.; Martos, M. Behavioural loyalty towards store brands. J. Retail. Consum. Serv. 2007, 14, 347-356. [CrossRef]

130. Pérez-Ordás, R.; Aznar Cebamanos, M.; Nuviala, R.; Nuviala, A. Evaluation of extracurricular sports activities as an educational element for sustainable development in educational institutions. Sustainability 2019, 11, 3474. [CrossRef]

131. Bandyopadhyay, S.; Martell, M. Does attitudinal loyalty influence behavioral loyalty? A theoretical and empirical study. J. Retail. Consum. Serv. 2007, 14, 35-44. [CrossRef]

132. Bitner, M.J. Evaluating service encounters: The effects of physical surroundings and employee responses. J. Mark. 1990, 54, 69-82. [CrossRef]

133. Homburg, C.; Giering, A. Personal characteristics as moderators of the relationship between customer satisfaction and loyalty-An empirical analysis. Psychol. Mark. 2008, 18, 43-66. [CrossRef] 
134. Dick, A.S.; Basu, K. Customer loyalty: Toward an integrated conceptual framework. J. Acad. Mark. Sci. 1994, 22, 99-113. [CrossRef]

135. Oliver, R.L. Satisfaction: A Behavioral Perspective on the Consumer; McGraw-Hill: New York, NY, USA, 1997.

136. Mittal, V.; Ross, W.; Baldasare, P. The asymmetric impact of negative and positive attribute-level performance on overall satisfaction and repurchase intentions. J. Mark. 1998, 61, 33-47. [CrossRef]

137. Krishnamurthi, L.; Raj, S.P. An empirical analysis of the relationship between brand loyalty and consumer price elasticity. Mark. Sci. 1991, 10, 172-183. [CrossRef]

138. Cong, L.C. A formative model of the relationship between destination quality, tourist satisfaction and intentional loyalty: An empirical test in Vietnam. J. Hosp. Tour. Manag. 2016, 26, 50-62. [CrossRef]

139. Kandampully, J.; Zhang, T.C. Customer loyalty: A review and future directions with a special focus on the hospitality industry. Int. J. Contemp. Hosp. Manag. 2015, 27, 379-414. [CrossRef]

140. Lin, H.; Wang, Y. An examination of the determinants of customer loyalty in mobile commerce contexts. Inf. Manag. 2006, 43, 271-282. [CrossRef]

141. Baabdullah, A.M.; Abdallah, A.; Rana, N.P.; Kizgin, H. Consumer use of mobile banking (M-Banking) in Saudi Arabia: Towards an integrated model. Int. J. Inf. Manag. 2019, 44, 38-52. [CrossRef]

142. Han, H.; Sean, S. Management Role of motivations for luxury cruise traveling, satisfaction, and involvement in building traveler loyalty. Int. J. Hosp. Manag. 2018, 70, 75-84. [CrossRef]

143. Bodet, G. Loyalty in sport participation services: An examination of the mediating role of psychological commitment. J. Sport Manag. 2011, 25, 458-473. [CrossRef]

144. Calabuig, F.; Prado-Gascó, V.; Crespo, J.; Núñez-Pomar, J.; Añó, V. Spectator emotions: Effects on quality; satisfaction, value, and future intentions. J. Bus. Res. 2015, 68, 1445-1449. [CrossRef]

145. Castillo-Rodríguez, A.; Onetti-Onetti, W. Perceived quality in sports centers in southern Spain: A case study. Sustainability 2019, 11, 3983. [CrossRef]

146. Haro-González, M.; Pérez-Ordás, R.; Grao-Cruces, A.; Nuviala, R.; Nuviala, A. Female users of unisex fitness centres and of fitness centres exclusive for women: Satisfaction. Int. J. Sport Mark. Spons. 2018, 19, 384-395. [CrossRef]

147. Howat, G.; Assaker, G. The hierarchical effects of perceived quality on perceived value, satisfaction, and loyalty: Empirical results from public, outdoor aquatic centres in Australia. Sport Manag Rev. 2013, 16, 268-284. [CrossRef]

148. Alexandris, K.; Zahariadis, C.; Tsorbatzoudis, C.; Grouios, G. An empirical investigation of the relationships among service quality, customer satisfaction and psychological commitment in a health club context. Eur. Sport Manag. Q. 2004, 4, 36-52. [CrossRef]

149. Alexandris, K.; Kouthoris, C. Personal incentives for participation in summer children's camps: Investigating their relationships with satisfaction and loyalty. Manag. Leis. 2005, 10, 39-53. [CrossRef]

150. Hong, I.B.; Cho, H. The impact of consumer trust on attitudinal loyalty and purchase intentions in B2C e-marketplaces: Intermediary trust vs. seller trust. Int. J. Inf. Manag. 2011, 31, 469-479. [CrossRef]

151. Martínez, P.; Del Bosque, I.R. CSR and customer loyalty: The roles of trust, customer identification with the company and satisfaction. Int. J. Hosp. Manag. 2013, 35, 89-99. [CrossRef]

152. Sirdeshmukh, D.; Ahmad, N.B.; Khan, M.S.; Ashill, N.J. Drivers of user loyalty intention and commitment to a search engine: An exploratory study. J. Retail. Consum. Serv. 2018, 44, 71-81. [CrossRef]

153. Sirdeshmukh, D.; Singh, J.; Sabol, B. Consumer trust, value, and loyalty in relational exchanges. J. Mark. 2002, 66, 15-37. [CrossRef]

154. Kassim, N.M.; Abdullah, N.A. Customer Loyalty in e-commerce settings: An empirical study. Electron. Mark. 2008, 18, 275-290. [CrossRef]

155. Nyffenegger, B.; Krohmer, H.; Hoyer, W.D.; Malaer, L. Service brand relationship quality: Hot or cold? J. Serv. Res. 2015, 18, 90-106. [CrossRef]

156. Gefen, D.; Karahanna, E.; Straub, D.W. Trust and TAM in online shopping: An integrated model. Manag. Inf. Syst. Q. 2003, 27, 51-90. [CrossRef]

157. Guinalı, M.; Gurrea, R.; Flavia, C. The role played by perceived usability, satisfaction and consumer trust on website loyalty. Inf. Manag. 2006, 43, 1-14.

158. Harris, L.C.; Goode, M.M.H. The four levels of loyalty and the pivotal role of trust: A study of online service dynamics. J. Retail. 2004, 80, 139-158. [CrossRef]

159. Kamboj, S.; Sarmah, B.; Gupta, S.; Dwivedi, Y. Management examining branding co-creation in brand communities on social media: Applying the paradigm of Stimulus-Organism-Response. Int. J. Inf. Manag. 2018, 39, 169-185. [CrossRef]

160. Bonsón Ponte, E.; Carvajal-Trujillo, E.; Escobar Rodríguez, T. Influence of trust and perceived value on the intention to purchase travel online: Integrating the effects of assurance on trust antecedents. Tour. Manag. 2015, 47, 286-302. [CrossRef]

161. Bairrada, C.M.; da Costa, J.F.; Araujo, M.C. Antecedents and consequences of e-satisfaction and e-loyalty: A study on sports nutrition brands. Int. J. Mark. Commun. New Media 2018, 6, 32-48.

162. Carlson, J.; Cass, A.O. Optimizing the online channel in professional sport to create trusting and loyal consumers: The role of the professional sports team brand and service quality. J. Sport Manag. 2012, 26, 463-478. [CrossRef] 
163. Na, C. Relationships among sport-products self-congruence, product love, product trust, and purchase behavior of sports-for-all club members. Korean J. Sport Sci. 2020, 31, 74-85.

164. Schijns, J.M.; Caniëls, M.C.; Le Conté, J. The impact of perceived service quality on customer loyalty in sports clubs. Int. J. Sport Manag. Recreat. Tour. 2016, 24, 43-75.

165. Tsiotsou, R.H. Sport team loyalty: Integrating relationship marketing and a hierarchy of effects. J. Serv. Mark. 2013, 27, 458-471. [CrossRef]

166. LaRiviere, J.; Czajkowski, M.; Hanley, N.; Aanesen, M.; Falk-Petersen, J.; Tinch, D. The value of familiarity: Effects of knowledge and objective signals on willingness to pay for a public good. J. Environ. Econ. Manag. 2014, 68, 376-389. [CrossRef]

167. Shukla, P.; Banerjee, M.; Singh, J. Customer commitment to luxury brands: Antecedents and consequences. J. Bus. Res. 2016, 69, 323-331. [CrossRef]

168. Gustafsson, A.; Johnson, M.D.; Roos, I. The effects of customer satisfaction, relationship commitment dimensions, and triggers on customer retention. J. Mark. 2005, 69, 210-218. [CrossRef]

169. Hennig-Thurau, T.; Gwinner, K.P.; Gremler, D.D. Understanding relationship marketing outcomes: An integration of relational benefits and relationship quality. J. Serv. Res. 2002, 4, 230-247. [CrossRef]

170. Pritchard, M.P.; Havitz, M.E.; Howard, D.R. Analyzing the commitment-loyalty link in service contexts. J. Acad. Mark. Sci. 1999, 27, 333-348. [CrossRef]

171. Rather, R.A.; Hollebeek, L.D.; Islam, J.U. Tourism-based customer engagement: The construct, antecedents, and consequences. Serv. Ind. J. 2019, 39, 519-540. [CrossRef]

172. Jung-Yong, L.; Chang-Hyun, J. How Collective Intelligence Fosters the Development of Incremental Innovation Capability. J. Open Innov. Technol. Mark. Complex. 2019, 5, 53.

173. Woodside, F.M.; Summers, J. The role of sponsor brand loyalty in sponsorship arrangements: FMCG context. In Proceedings of the Australian and New Zealand Marketing Academy Conference (ANZMAC 2010), University of Canterbury, Christchurch, New Zeland, 29 November-1 December 2010; pp. 1-8.

174. Čater, T.; Čater, B. Product and relationship quality influence on customer commitment and loyalty in B2B manufacturing relationships. Ind. Mark. Manag. 2010, 39, 1321-1333. [CrossRef]

175. Bloemer, J.; Odekerken-Schröder, G. The psychological antecedents of enduring customer relationships: An empirical study in a bank setting. J. Relatsh. Mark. 2007, 6, 21-43. [CrossRef]

176. Bansal, H.S.; Irving, P.G.; Taylor, S.F. A three-component model of customer commitment to service providers. J. Acad. Mark. Sci. 2004, 32, 234-250. [CrossRef]

177. Kumar, N.; Hibbard, J.; Stern, L. The Nature and Consequences of Marketing Channel Intermediary Commitment; Marketing Science Institute: Cambridge, MA, USA, 1994.

178. Iwasaki, Y.; Havitz, M.E. Examining relationships between leisure involvement, psychological commitment and loyalty to a recreation agency. J. Leis. Res. 2004, 36, 45-72. [CrossRef]

179. Cater, B.; Zabkar, V. Antecedents and consequences of commitment in marketing research services: The client's perspective. Ind. Mark. Manag. 2009, 37, 785-797. [CrossRef]

180. De Ruyter, K.; Moorman, L.; Lemmink, J. Antecedents of commitment and trust in customer-supplier relationships in high technology markets. Ind. Mark. Manag. 2001, 30, 271-286. [CrossRef]

181. Rauyruen, P.; Miller, K.E. Relationship quality as a predictor of B2B customer loyalty. J. Bus. Res. 2007, 60, 21-31. [CrossRef]

182. Meyer, J.P.; Stanley, D.J.; Herscovitch, L.; Topolnytsky, L. Affective, continuance, and normative commitment to the organization: A meta-analysis of antecedents, correlates, and consequences. J. Vocat. Behav. 2002, 61, 20-52. [CrossRef]

183. Evanschitzky, H.; Iyer, G.R.; Plassmann, H.; Niessing, J.; Meffert, H. The relative strength of affective commitment in securing loyalty in service relationships. J. Bus. Res. 2006, 59, 1207-1213. [CrossRef]

184. Fullerton, G. How commitment both enables and undermines marketing relationships. Eur. J. Mark. 2005, 39, 1372-1388. [CrossRef]

185. Harrison-Walker, J.L. The measurement of word-of-mouth communication and an investigation of service quality and customer commitment as potential antecedents. J. Serv. Res. 2001, 4, 60-75. [CrossRef]

186. Hay, R.; McDonald, H. A victory for the fans? Melbourne's new Football club in recent historical perspective. Soccer Soc. 2007, 8 , 298-315. [CrossRef]

187. Dwyer, B.; Greenhalgh, G.P.; LeCrom, C.W. Exploring fan behavior: Developing a scale to measure sport eFANgelism. J. Sport Manag. 2015, 29, 642-656. [CrossRef]

188. Hebles, M.; Prado-Gascó, V.J.; Llanos-Contreras, O.; Alguacil, M. The influence of emotion in the management of amateur football organizations. Front. Psychol. 2020, 11. [CrossRef]

189. Bilgihan, A.; Bujisic, M. The effect of website features in online relationship marketing: A case of online hotel booking. Electron. Commer. Res. Appl. 2015, 14, 222-232. [CrossRef]

190. Nusair, K.; Bilgihan, A.; Okumus, F.; Cobanoglu, C. Generation Y travelers' commitment to online social network websites. Tour. Manag. 2013, 35, 13-22. [CrossRef]

191. Inoue, Y.; Funk, D.C.; McDonald, H. Predicting behavioral loyalty through corporate social responsibility: The mediating role of involvement and commitment. J. Bus. Res. 2017, 75, 46-56. [CrossRef] 
192. Kim, S. Investigating the Impact of Corporate Social Responsibility on Conative Loyalty in Collegiate Sports. 2017. Available online: https: / / scholarworks.uark.edu/etd/2450 (accessed on 27 October 2020).

193. Hair, J.F.; Ringle, C.M.; Sarstedt, M. PLS-SEM: Indeed a silver bullet. J. Mark. Theory Pract. 2011, 19, 139-152. [CrossRef]

194. Esposito Vinzi, V.; Chin, W.W.; Henseler, J.; Wang, H. Handbook of Partial Least Squares. Concepts, Methods and Applications; Springer: New York, NY, USA, 2010.

195. Henseler, J.; Ringle, C.M.; Sarstedt, M. Using partial least squares path modeling in advertising research: Basic concepts and recent issues. In Handbook of Research on International Advertising; Edward Elgar Publishing: Cheltenham, UK, 2012.

196. Nunnally, J.C.; Bernstein, I.H. Psychometric Theory, 3rd ed.; McGraw-Hill: New York, NY, USA, 1994.

197. Fornell, C.; Larcker, D.F. Structural equation models with unobservable variables and measurement error: Algebra and statistics. J. Mark. Res. 1981, 18, 39-61. [CrossRef]

198. Bove, L.L.; Pervan, S.J.; Beatty, S.E.; Shiu, E. Service worker role in encouraging customer organizational citizenship behaviors. J. Bus. Res. 2009, 62, 698-705. [CrossRef]

199. Walsh, G.; Beatty, S.E.; Shiu, E.M. The customer-based corporate reputation scale: Replication and short form. J. Bus. Res. 2009, 62, 924-930. [CrossRef]

200. Chang, S.J.; Van Witteloostuijn, A.; Eden, L. From the editors: Common method variance in international business research. J. Int. Bus. Stud. 2010, 41, 178-184. [CrossRef]

201. Podsakoff, P.; MacKenzie, S.; Lee, J.-Y. Common method biases in behavioral research: A critical review of the literature and recommended remedies. J. Appl. Psychol. 2003, 88, 879-903. [CrossRef]

202. Kock, N. Common method bias in PLS-SEM: A full collinearity assessment approach. Int. J. eCollab. 2015, 11, 1-10. [CrossRef]

203. Chin, W.W. The Partial Least Squares Approach for Structural Equation Modeling. In Modern Methods for Business Research; Mahwah, N.J., Marcoulides, G.A., Eds.; Lawrence Erlbaum Associates: Mahwah, NJ, USA, 1998; pp. $295-336$.

204. Bagozzi, R.P.; Heatherton, T.F. A general approach to representing multifaceted personality constructs: Application to state self-esteem. Struct. Equ. Model A Multidiscip. J. 1994, 1, 35-67. [CrossRef]

205. Chin, W.W. How to write up and report PLS analyses. In Handbook of Partial Least Squares; Esposito Vinzi, V., Ed.; Springer: Berlin, Germany, 2010; pp. 655-690. [CrossRef]

206. Demirci, F.; Kara, A. Supermarket self-checkout service quality, customer satisfaction, and loyalty: Empirical evidence from an emerging market. J. Retail. Consum. Serv. 2014, 21, 118-129. [CrossRef]

207. Hur, Y.; Ko, Y.J.; Valacich, J. A Structural model of the relationships between sport website quality, e-satisfaction, and e-loyalty. J. Sport Manag. 2011, 25, 458-473. [CrossRef]

208. Gutiérrez Rodríguez, P.; Burguete, J.L.; Vaughan, R.; Edwards, J. Quality dimensions in the public sector: Municipal services and citizen's perception. Int. Rev. Public Nonprofit Mark. 2009, 6, 75-90. [CrossRef]

209. Gundlach, G.T.; Achrol, R.S.; Mentzer, J.T. The structure of commitment in exchange. J. Mark. 1995, 59, 78-92. [CrossRef]

210. McClung, S.; Rynarzewska, A.I. Purchase intention behind Mercer University's inaugural football team. Int. Rev. Public Nonprofit Mark. 2015, 12, 155-167. [CrossRef]

211. Matzler, K.; Grabner-Kräuter, S.; Bidmon, S. Risk aversion and brand loyalty: The mediating role of brand trust and brand affect. J. Prod. Brand Manag. 2008, 17, 154-162. [CrossRef]

212. Kotler, P. Strategies for introducing marketing into nonprofit organizations. J. Mark. 1979, 43, 37-44. [CrossRef]

213. Cuesta-Valiño, P.; Loranca-Valle, C.; Núñez-Barriopedro, E. La Promoción del Deporte a través de la Felicidad del Deportista Federado en Kárate. ADRes. ESIC 2020, 21, 48-69. [CrossRef]

214. Chi, C.G.; Qu, H. Examining the structural relationships of destination image, tourist satisfaction and destination loyalty: An integrated approach. Tour. Manag. 2008, 29, 624-636. [CrossRef]

215. Dagger, T.S.; Sweeney, J.C. The effect of service evaluations on behavioral intentions and quality of life. J. Serv. Res. 2006, 9, 3-18. [CrossRef]

216. Hutchinson, J.; Lai, F.; Wang, Y. Understanding the relationships of quality, value, equity, satisfaction, and behavioral intentions among golf travelers. Tour. Manag. 2009, 30, 298-308. [CrossRef]

217. Loranca-Valle, C.; Cuesta-Valiño, P.; Núñez-Barriopedro, E. Quality Management as a key strategy for happiness in federationbased sport. RETOS Rev. Cienc. Adm. Econ. 2019, 9, 203-218. 